\title{
RESEÑAS
}

Gerardo Sáenz, Luis G. Urbina, vida y obra. México: Colección Studium, 31; Ediciones De Andrea, 1961.

Carácter de definitivo adquiere este primer estudio serio que de Urbina se ha realizado, no obstante ciertas flaquezas que se advierten en el mismo. En lo que al estudio de la obra se refiere puede calificársele de bueno; en lo concerniente al aspecto biográfico hay que otorgarle rango de excelencia. Tal vez no sea justo aislar ambos elementos al tratar de analizarlos, ya que el autor nos dice que "es preciso conocer la vida de Urbina para valorar su obra - siendo como son inseparables-, y ésta es la razón de ser del presente trabajo." El profesor Sáenz, muy acertadamente, cristaliza en el título este maridaje de "vida y obra". Sin embargo, es aquí, precisamente, donde aparece la primera falla, o por lo menos una inconsistencia básica. Aunque el autor declara que el "Viejecito" es un gran escritor - "al par con la obra de Manuel Gutiérrez Nájera está la de Urbina"no deja que Urbina escritor supere a Urbina hombre. Es obvio que la obra de todo poeta de primera categoría supera los aspectos biográficos de su autor, y es posible llegar a una evaluación de ella sin tener antecedentes biogtáficos del artista aunque sea muy interesante su conocimiento. Esto es lo que ocurre en el caso de Gutiérrez Nájera. Por lo tanto, parécenos inexacto decir que la obra de Urbina está al par con la de aquél. No obstante, hay que aceptar a Urbina como un gran poeta y no negarle el rango de importancia por él adquirido en las letras mexicanas. El descubrimiento biográfico de Sáenz, lejos de cambiar el sentido de la obra del poeta, la enriquece.

El estilo literario del biógrafo de Utbina da gran realce al estudio; de aquí que se le califique de excelente. No es sorprendente que un estudioso realice investigaciones minuciosas, cosa que ha hecho Sáenz, valiéndose de documentos y entrevistas a personas que conocieron o tuvieron algún contacto con Urbina. Lo que si sorprende agradablemente es la prosa amena con que nos ofrece el resul. tado de sus investigaciones. Urbina no es un ente literario sino el real protagonista de su biografía. Se ve el hombre entero; y si la biografía es, hasta cierto punto, una apología, no es una idealización. La única debilidad que se encuentra en la caracterización se halla en el capítulo intitulado "El Revolucionario." Sáenz quiere demostrar cietta relación ideológica entre Urbina y la Revolución, y no la hace, porque Urbina no fue revolucionario ni pudo serlo. Como tantos otros 
intelectuales de buena voluntad que nunca entendieron el significado de la Revolución, Urbina quiso integrarse en la nueva vida mexicana y no supo hacerlo. Con todo, Urbina es un personaje humano y creíble. $Y$ este personaje no vive solo, ya que anda por las páginas del libro de Sáenz acompañado de sus parientes, sus amigos y sus conocidos: Lucecita, Justo Sierra, el músico Villanueva, Rafael López, etc. El autor recrea el sabor de aquella época extraordinaria y nos ofrece un gran caudal de la vida literaria de entonces.

Como ya indicamos, consideramos que la crítica es inferior a la biografía; pero para ser justo, recalcamos que Sáenz cree que, en el caso de Urbina, la una no existe en la otra. No nos parece que sean tan inseparables porque, al leer el estudio, nos ha molestado la intrusión de la crítica cada vez que ésta rompia la excelente narración. La crítica que hace Sáenz es más descriptiva que analítica. Su técnica es comentar la forma de la poesía y luego explicar cómo se relacio. nan la materia y la vida del poeta.

Sáenz nos ha presentado a un Urbina mucho más acabado que el que veíamos antes. Además del gran lírico, vemos al Urbina de los epigramas; vemos al pobre poeta patrocinado y al gran poeta patrocinador; vemos al hombre de grandes principios y al hombre de flaquezas terriblemente humanas. El biógrafo encuentra cada una de las facetas del poeta captadas en su obra. Lamenta el autor que muchos conozcan sólo al poeta de la "vieja lágrima." Ahora podemos contemplat al hombre entero, pero a nuestro juicio, el "Viejecito" sigue siendo el poeta de la melancolía, que es la esencia de su obra, a pesar de las otras facetas. Dudo que existiera amistad más significativa que la de Urbina y el pianista Felipe Villanueva, cuyo "Vals poético" pudiera acompañar a los versos más típicos del bardo. Si el Urbina que permanece con nosotros al finalizar el libro no es precisamente el escritor que Sáenz se propuso retratar, por lo menos la biografía es de tal calidad que el hombre-escritor es perfectamente creíble y muy admirable.

University of Missouri

JOHN S. BRUSHWOOD

Yerro Moretic, El relato de la pampa salitrera. Santiago de Chile: Ediciones del Litoral, 1962.

Esta obra incluye los principales cuentos y novelas que tratan de la vida en la región norte de Chile, en la cual se encuentran los grandes yacimientos de salitre y de cobre, las instalaciones y campamentos alli establecidos por diversas empresas y algunas ciudades que, como Iquique y Antofagasta, dependen directa o indirectamente de la actividad minera de la zona.

El recuento de las producciones novelescas hecho por Moretic se inicia con Leyendas pampinas (1907), suscritas por T. D. Monto, y concluye con Los pampinos (1956), de Luis González Zenteno. Los escritores incluidos dentro de este período son todos chilenos. De ellos no se hace nómina alguna, así como tampoco se da un índice de sus obras o de las materias estudiadas en los diversos capítulos. 
Por los datos proporcionados en las solapas del libro nos informamos de que en 1953 Yerko Moretic presentó su estudio al Instituto Pedagógico de la Universidad de Chile como tesis de prueba para optar al título de profesor de castellano. En 1960 el mismo ensayo, según parece, se hizo merecedor del Premio Gabriela Mistral. Durante varios años Moretic ha venido haciendo labor de critica literaria en diversas revistas, tales como Atenea, Ultramar, Boletin de la Sociedad de Escritores y otras.

La labor realizada por este crítico tiene el mérito de haber reunido gran parte del abundante repertorio de cuentos y novelas que por espacio de más de medio siglo ha venido teniendo por escenario la vida de una de las regiones más típicas de Chile. Aunque no se desconocían las obras inspiradas por la pampa, con este trabajo se constata la magnitud que ellas poseen, el grado de variedad alcanzado por el tema y la orientación seguida por los diversos autores.

El orden cronológico a que con frecuencia se ha ceñido Moretic guarda es. trecha relación con la pauta que se ha impuesto para clasificar las obras y encuadrarlas dentro de moldes interpretativos trazados con severa rigidez. Un primer apartado, por ejemplo, se titula "El ascenso mesoctático", y un segundo encasiIlamiento se denomina "El surgimiento del proletariado". En el primero hay dos subdivisiones temáticas - "Realismo ingenuo" y "Populismo-psicologismo", pero el autor pronto olvida este procedimiento y empieza a tratar a los autores por orden cronológico. Dos páginas de "Conclusiones" cierran la obra.

El tratamiento de la materia sigue consignas marxistas rígidas y estrechas. No se salvan de la inexorable guillotina partidista sino aquellas obras que ilustran dogmas tales como la lucha de clases, la redención del proletariado por medio de la violencia y la aversión ciega al capital extranjero. De todo ello resulta que el enfoque crítico, si bien sincero, se torna algo viciado por prejuicios políticos inaceptables.

Ocasionalmente se alude a uno que otro aspecto estilístico, rara vez a la técnica novelística y casi nunca a la proyección de las obras en el desarrollo evolutivo de las letras chilenas. Ocupa el autor un buen número de páginas en contarnos el asunto de las narraciones a fin de realzat la presencia del conflicto social que le preocupa o para castigar al escritor por haberse desentendido de dicho tema. El espacio dedicado al análisis e interpretación artística de las creaciones resulta, pues, insignificante. Algunos juicios generalizadores, por otra parte, exigirían amplias pruebas documentales para llegar a ser aceptados.

Concluye Moretic que la literatura novelesca de la pampa se inicia como un "afán de dar a conocer las particulatidades específicas de la región" pero que, como "la aventura humana es ineludible", ésta se manifiesta "primero, a través de un superficial pintoresquismo; luego con el propósito de mostrar el influjo de esa naturaleza...; en tercer lugar, mediante la conmiseración que despierta en el artista la desmedrada suerte de los trabajadores". Refiriéndose a las manifestaciones novelescas más recientes el crítico declara que "bajo la advocación de un individualismo desintegrador - portan la visión escéptica y pesimista de hombres que, sujetos al dominio burgués, sienten derrumbarse el mundo en el cual se formaron." Adelantándose al desacuerdo que ha de surgir por la manera en que el autor ha tratado la materia, éste confiesa que "la 
nomenclatura empleada está sujeta a revisión, ya que, inclusive, no siempre corres. ponde a la usada tradicionalmente en los tratados de crítica e investigación literaria."

Aparte del inventario a que ya nos hemos referido, nos parece que esta obra vale por abrir un campo que resistirá estudios más acusiosos. Certero se muestra Moretic al afirmar que "aquí sólo se proporcionan atisbos de valor muy circunstancia!".

Nortbwestern University

Homero Castillo

Salvador Novo. Poesía. México: Fondo de Cultura Económica (Serie Letrás Mexicanas), 1961. Yocasta, o casi. México: Los Textos de La Capilla, IIl, 1961.

La extensa y variada producción literaria de Salvador Novo ocupa un lugat insustituíble en las letras mexicanas contemporáneas, y es de importancia notar la aparición casi simultánea de dos abras que definen y continúan esa producción. Poesía, cuidadosamente editada en Letras Mexicanas como cuadro selecto de la expresión poética de Novo, es en realidad una nueva edición de Poesía, 1915-1955, publicada en la Colección Lince en 1955. La comparación entre las dos ediciones indica que unas facetas de la producción de Novo quedan bastante alteradas en la edición de Letras Mexicanas, mientras que figuran sin variar sus obras máximas (XX poemas, 1925; Espejo, 1933; Nuevo amor, 1933). Por ejemplo, los "Poemas de infancia", 1915-1916 (coleccionados por primera vez en la edición de 1955) se han suprimido por completo, como lo fueron 15 de los "Poemas de adolescencia, 1918-1923" (también coleccionados por primera vez en 1955). No figuran los cuatro sonetos de Dieciocho sonetos (1955), ni tampoco las traducciones de poetas norteamericanos hechas en 1924-1925. Sin embargo, estos cambios son leves, y sólo hacen que en la edición de Letras Mexicanas se destaque lo más significativo de la poesía de Novo. De mayor importancia tal vez sea la omisión de unos comentarios que en 1955 Novo hiciera sobre su propia poesía, tales como la "Consideración preliminar", breves reflexiones sobre cada uno de sus libros, y "Poética", texto en el que Novo se declaraba poeta frustrado.

Yocasta, o casi, pieza de tres actos que fue estrenada en 1961 en el Teatro Xola, y que aparece ahora como el tomo tercero en la serie "Textos de la Capilla", constituye una notable adición a la obra teatral de Novo. Distinta de La culta dama (1951), crítica de la institución de la mujer caritativa, y de $A$ ocbo columnas (1956), comedia algo romántica que versa sobre los males del periodismo, Yocasta, o casi es más bien una interpretación de la vida que una crítica de determinado sector de la sociedad. Utilizando como fondo una combinación de elementos mitológicos, teatrales y psiquiátricos, Novo medita por medio de sus personajes la inevitable confrontación de lo ideal con lo real. Alberto, comer- 
ciante acaudalado que en su juventud había tenido de amante a una joven actriz, vuelve a ver de nuevo a la mujer de sus sueños, ahora Dora Lamont, actriz famosa que reside de incógnito en Acapulco acompañada de su psiquiatra. Alberto siente renacer su antigua pasión, pero la situación se complica con los enredos de los personajes secundarios: Horacio dice que es hijo de Dora y que como psiquiatra quiere ayudarle a clarificar su vida confusa; Carlota, hija de Alberto, sueña con ser actriz y toma como ideal a Dora; Mario, novio de Carlota e hijo de un hombre que también había sido amante de Dora, corresponde al interés que Dora manifiesta por él. En una escena violenta con Dora, Alberto trata de revivir la pasión de su juventud, pero se da cuenta de que la realidad es otra. Al final todo se resuelve: Carlota va a estudiar psiquiatria al lado de Horacio, que no es hijo de Dora; Mario decide entregarse a la realidad de su juventud y no a la deslumbrante atracción de una mujer famosa. Y Dora, por poco la Yocasta mitológica, desaparece de la vida de todos.

Yocasta, o casi es teatro de ideas. La trama es forzada y los personajes son extremados, pero en conjunto contribuye a dar una expresión filosófica de la vida. Debemos conformarnos, dice Novo, con la realidad de nuestra situación y no dejar pasar la vida anhelando lo imposible. Alberto no puede volver a encontrar la pasión loca de su juventud, y al intentarlo, se pone en tidículo. Carlota no tiene el talento para ser actriz, $y$ hace bien en dejar esa ilusión. Mario no debe buscar en la fama de Dora un fin digno de su juventud fogosa. Sólo el artista, afirma Novo por medio de Dora, tiene el derecho y la capacidad de vivir en el mundo de los sueños. Allí, separado del mundo real y condenado por eso a una inmortalidad brillante y a veces vacia, puede rendir nueva comprensión a los habitantes del mundo tangible. Como dice Dora Lamont para cerrar la pieza: "Hablen de la heroína... discútanla, analícenla, entiéndanla, si pueden. $Y$ olvídenla. Ella pertenece a otro mundo. $Y$ en él ha de seguir consumiéndose, angustiada y dichosa, hasta el últino aliento de su pasión."

University of Illinois

Merlin H. Forster

Agustín Yáñez. La tierra pródiga. México: Fondo de Cultura Económica [Colección Popular No. 19], 1950.

A la experiencia y conocimiento de la vida mexicana que Agustín Yáñez había alcanzado como maestro, historiador y escritor, añadió a partir de 1953 la experiencia política en un grado que es poco frecuente entre los escritores mexicanos: el del jefe del ejecutivo de un gobierno estatal. Semejante experiencia es fundamental para un escritor mexicano del siglo xx. La política es un tema atractivo, inquietante: peto es además un personaje misterioso, a fuerza de ser familiar para los mexicanos. Ese personaje, nás que el propio tema, ha sido diseñado en la novelística mexicana, de manera predoninante, desde fuera, por el espectador, más frustrado que contemplativo; ha sido conocido por sus rasgos 
más aparentes, con frecuencia burdos además de vulgares. No puede ser de otra manera, pues el escritor mexicano, que suele ser escriba de políticos, pocas veces llega a penetrar los entedos íntimos de la política; puede ser un enterado, pero no es necesariamente un conocedor; no lo es, al menos, en la medida en que un conocimiento exige de la participación.

Si el novelista ayudó al político y al gobernante en el caso de Yáñez, ahora el político ha venido en auxilio del novelista; el gobernante mismo ha permitido que este conocedor de hombres - que lo era desde antes de gobernarlo sea en un periplo más amplio y más intenso. El novelista ha conocido hombres que no sólo pueden ser conocidos por el gobernante y el político, ciertamente, pero a quienes la mirada de quien tiene el poder somete a una especie de prisma que revela a un tiempo ángulos y rasgos distintos, que otros hombres que los tratan no suelen captar.

La novela de Yáñez no es precisamente una novela de políticos; pero la política está presente en todo el curso del relato. El hecho mismo que da origen al cuento es de política económica: el desarrollo de una región de la costa del Pacífico, en Jalisco. Es la destrucción del cacicazgo de tipo más o menos tradicional, de acusados rasgos feudales, para dar lugar a la economía capitalista, encauzada y promovida - ya que no dirigida - por el Estado. Pero esos mismos caciques, cuyos señoríos de la tierra serán derrumbados, son seres de transición, condicionados ya por una revolución prolongada, que a pesar de las contradicciones que no ha podido resolver $y$ que han dado lugar a traiciones oscuras y brillantes, cambió la estructura social y económica del país y le dio instituciones nuevas sin cuyo conocimiento toda la situación de México se antoja inexplicable.

Los señores de la tierra, que forman esa "rueda de fieras" temerosas de ser desplazadas de "sus" dominios y zonas de influencia, no fundan ya su poder en las más antiguas fuerzas militares y eclesiásticas; al lado de quienes tienen aún esos apoyos, están quienes los reciben del poder civil; una lista de los actuales señores de la tierra y de sus sostenes determinantes - nunca exclusivos- esclarecerá fácilmente este punto: Eulogio Parra "se ha dormido al gobernador y le ha sacado un millón de pesos dizque para tener en paz la comarca mediante préstamos agrícolas en fideicomiso..."; Tiburcio Lemus "picará más alto, conchavará a las meras autoridades federales..."; Pánfilo Rubio "se las arreglará con los mandones locales... resultan mejor para dejar arregladas las cosas o echarles tierra"; Ricardo Guerra, El Amarillo, "su gran ventaja local sobre los otros es la amistad con el obispo"; Sotero Castillo "se acoge al patrocinio de altos jefes militares y completa sus cuadros con líderes agrarios"; Pablo Flores es aliado del terrateniente ausentista y usurero, "que sin pararse nunca en la costa interviene decisivamente desde Autlán, desde Mascota, desde Guadalajara, que son sus residencias alternadas, al grado de decirse corrientemente: 'no se mueve la hoja de un árbol en la costa sin la voluntad de don Chucho Cordero', lo que pone fuera de sí a sus rivales...."

Sí, todos los personajes de la novela son rivales. No sólo éstos, que son los principales con el ingeniero Pascual Medellín (el promotor que personifica al gobierno en lo que tiene de continuidad en esfuerzo creador y no en lo que pueda significar de abuso del poder para beneficio personal de quienes circunstancial- 
mente lo integran); también las mujeres como Elena y Gertrudis; también la tierra, que necesita ser dominada como las mujeres; la naturaleza, que a veces se rebela poderosa y destructora. La novela refleja esa rivalidad; la lucha de opuestos que a veces estalla con violencia y otras se mantiene en el orden de la marrullería, la astucia, el juego sucio por la posesión, el dominio, la explotación de la tierra.

La mayoría de los personajes no es de hombres a quienes la "Revolución les haya hecho justicia", según un dicho común en México, sino de hombres que se han hecho justicia con la Revolución, o al menos, que se han hecho a sí mismos, en la etapa constructiva de la Revolución. Son hombres de frontera, conquistadores actuales que, igual que los de ayer, se valen de la fuerza y la astucia, del regateo y de la usura, del enganchamiento (nueva encomienda) y de las guardias blancas para construir imperios aún más fugaces, peto igualmente crueles.

Yáñez los toma en el momento en que los avances del desarrollo económico, apoyado en la planeación, llegan hasta sus dominios y los amenazan. Las reacciones de los distintos dueños son diferentes; todos temen; unos se resisten; uno trata de montarse en la ola que llega; es el que se transformatá quizá con las brechas que se convierten en caminos, el que acaso coadyuve a construir un emporio de riquezas que alcancen a un mayor número de personas, aunque no se funde en un cambio social profundo, es Ricardo Guerra Victoria, el Amarillo, el personaje principal de la novela.

Su historia es la que se cuenta con mayor detalle - por lo que hace al pasado y por lo que toca al presente-; es el corifeo de un coro que se queda rezagado, con el que está en pugna, con el que lucha a muerte. Es el advenedizo que no se resiste a ser sobrepasado por las cosas que vienen. Es el más apto; en esta lucha feroz, de jungla de árboles, de jungla de asfalto, es el que subsiste; se alía con las máquinas, con el crédito, con las instituciones, con los planes del gobierno; se apoya en los funcionarios, en la iglesia, en los artistas de cine, en los periodistas. Piensa constantemente en el turismo, en los proyectos grandiosos. Se vale de todo, del amor, la amistad, la traición; de los viejos usos que dan fuerza a los caciques, de los nuevos que dan fuerza a los hombres de empresa. Del salvajismo rural salta a la barbarie civilizada.

Tiene una moral: triunfar, imponerse, hacer lo que se propone. Es tisueño, zalamero, seductor. Sabe ganarse a los pistoleros de sus enemigos; matar cuando es necesario. No ha heredado sus dominios y está dispuesto a conservarlos y ampliarlos; no se resiste como los demás al embate de lo nuevo; se monta en lo nuevo. Sonriente, trata de abrazar a los que lo vencen; es en vano, "y se conforma con que le den la mano". Solícito, servicial, recurre al halago después de perder la fuerza. No quiere ser desplazado. Ofendido por la realidad de un trato áspero de parte de las autoridades, malicia en sus meditaciones: Más adelante mañana con las viejas las mujeres destos como aliadas encandiladas con el mar bablaremos convertidas en aliadas como la otra vez las caras nos veremos méndigos qué dijeron frente a éste nada valemos juntos pero detrás de nosotros toda una maquinaria lo apabullará mañana veremos.

Dice en voz alta: "Con voz categórica, retadora: - Tendremos que poder". Afronta la derrota; pero no se da por vencido.

Yáñez, narrador experto, dueño de un lenguaje poderoso y rico, es apenas, 
en breves períodos, quien cuenta la historia. Ha usado del diálogo, del monólogo en voz alta y del monólogo interior para la mayor parte de su novela. Estos procesos discursivos se interrumpen con frecuencia unos por otros; son por lo general las voces y los pensamientos de los personajes; predomina el principal: el Amarillo; a veces se advierte el testimonio de alguien que se antoja el promotor, el ingeniero Pascual Medellín, pero que puede ser el Gobierno, o el Gobernador, Yáñez o el tiempo, encarnado en la gente del pueblo; esos párrafos tienen el sabor de conseja, de rumor murmurado por mujeres enlutadas, en las calles polvosas de algún pueblo; de vez en cuando, se percibe la satisfacción, tenue en su apariencia, como de quien la tiene profunda, de quien sabe que venció a la rueda de fieras.

Las figuras femeninas, mantenidas en un segundo plano, son atractivas, Elena esposa del Amarillo, Gertrudis - hija de Sotero Castillo el torvo cacique de origen militar - a quien aquél seduce y rapta; la mujer de Sotero Castillo, vengativa, dibujada apenas, con unas cuantas líneas y unas palabras que dice:

"Ultimo acto en el duelo de Nacastillo, la viuda de Sotero manda rociar con petróleo el comando, le prende fuego, hace recoger los restos y se los remite al Amarillo, 'para que sepa lo que se le espera'.

"-Y díganle que allí van achicharrados algunos gusanos de su víctima, por si se los quiere tragar en agua de uso con su par de cuscas, para que más pronto le salgan cuernos, mientras voy y se los quiebro en añicos, con todos los huesos, al machorro infeliz."

Han sido destruidos los caciques; pero el pueblo no ha sido liberado aún. El vencido se propone, así, volver a empezar.

El saldo de esta novela de Agustín Yáñez, a la que pronto seguirá otra sobre Las tierras flacas, es rico: ha abierto una nueva perspectiva a la novelística mexicana, la -evasiva - de una realidad cambiante, dinámica, que oculta aun los rasgos de los nuevos tipos que ha producido bajo los rasgos viejos de los personajes que fueron típicos en un mundo que se acaba, pero que aún subsiste poderoso; esa perspectiva compleja, contradictoria y sin embargo monótona en sus aspectos más acentuados, ha sido expresada con su propio lenguaje: el que corresponde a la gente y al paisaje que permite ver. Enriquece, pues, la literatura mexicana: con una nueva y profunda experiencia humana que permanecía inédita y era difícil de captar porque su esencia está en su índole cambiante; con un lenguaje popular que ha logrado someter al dominio del arte.

Universidad Nacional

Autónoma de México

Henrique González Casanova

Ciemente Arró, La ciudad y el viento. Bogotá: Ediciones Espiral, 1961.

Clemente Airó, nacido en Madrid, España, en 1918 y residente en Colombia desde 1941, fundador y director de la revista Espiral y de la Editorial Iqueima, 
ha producido su tercera novela con éxito que ha pasado las fronteras. El lector desprevenido sorprende en ella la estructura técnica: no hay capítulos sino apartes; hay mezcla de letra bastardilla y cursiva; cada aparte lleva descripciones o trozos de una vida, que quedan en suspenso. Los personajes aparecen de pronto, sin previa presentación, a veces sin nombres y sin descripción física. Al fondo, la ciudad de Bogotá y sus alrededores; en ella, una hora de día que une existencias en el "leit-motiv" de sus paisajes o de sus estados. Una idea central: el crecimiento de la ciudad, la ciudad en evolución, como dice el autor, que circunda al espiritu, lo desorienta, lo lleva a buscar caminos equivocos para alcanzar el triunfo, al escape, a la quiebra de valores, al retraso cultural y moral.

Airó confiesa dos influencias: Dos Passos y Virginia Woolf. De ésta dice haber tomado los aspectos poéticos -o sea aspectos creadores-; se le asemeja en la técnica impresionista y en el examen del subconsciente. De Dos Passos ha tomado el lente que va destacando del fondo colectivo, pero, puede agregarse, el sentido de lo colectivo.

Trata con afecto a los personajes, que él ha conocido; por eso no se desvía hacia el naturalismo, aunque a veces caiga en él; ese afecto no impide una visión global realista y pesimista. Doquiera la intriga y las malas artes: se pierden unos en el desencanto y la desilusión, otros alcanzan las cimas. El político queda buscando caminos mejores entre las reflejadas costumbres de los suyos. Tres se salvan: Elvira, la mecanógrafa, "un animalito puro", según definición de Airó; Don Carlos Camacho, hombre de alta sociedad replegado en su retiro, unido al mundo sólo por la cátedra universitaria, con fe en el futuro y sin fe en el presente; Leonor, en lucha ardua por la supervivencia, resuelta a levantar la cultura musical desde su hogar desgraciado, a quien la misma ciudad rechaza finalmente. En medio a la doblez y a la mentira, el Chivo, anciano mendigo, puente tendido al pasado. Aun Inés, con particulares condiciones de educación y de bondad, es capaz de cambiarlo todo por la ambición. Y don Ricardo, el negociante sin escrúpulos; Patricia, su hija, con alma de barriada; Armando, el arrivista, duro y brutal atrabiliario, como otros lo fueron con él. Y Vicente, el dipsómano por causa de su fracaso; y Ramón, el estudiante idealista que no halla camino para realizar sus sueños; y Elvia, la secretaria, desegañada, que está de regreso; y el espía a sueldo de don Ricardo...

Hasta la ciudad las voces de la violencia; en ella la miseria, los aprovechadorés de esa violencia, el olvido de la buena fe, la política mezquina, las perrogativas de clase. El bogotano tradicional que en pequeña minoría guarda ciertos valores, y que no se ha tomado el trabajo de mirar en torno, queda desconcertado. Airó, colombiano de ultramar, ha mirado objetivamente. El bogotano se pregunta: ¿y el alma de la ciudad? ¿La ha perdido? ¿La ha vendido? ¿Se ha perdido como las mansiones señoriales, a las que se refiere La ciudad y el viento, hoy cafetines y "danzings", sitios de hacinamiento de toda clase de seres, de músicas vulgares, de escenas indeseables y de falta de higiene? Evidentemente Airó miró todo o casi todo. No miró al obrero y pasó por alto la ciudad en sordina, la que habla bajo, la que valora los matices, la ciudad perezosa, ingeniosa y honesta, cuya misma honestidad la oculta pero donde todavía vive lo generoso y heroico. No miró al Palacio de los Presidentes desde 1958. 
El autor cree que la expresión idiomática necesita impurezas para darle vitalidad; quizá por eso olvida en ocasiones la armonía temporal: "Hubo momentos en que las fuerzas estuvieron equilibradas y es cuando el cacique pide otro refuerzo" (p. 146). Olvida a veces la concordancia: "Ese ganado domina los potreros con solemnidad de ídolos". Frases como: "El mayor cáncer del país y al cual debemos dar una batalla campal para exterminarlo, es el avance personal a base de intriga" (p. 261) o como: "...y el ánimo dispuesto para degustar la belleza del panorama de la naturaleza" (p. 20) no se compadecen con descripciones tan finas como ésta: "En esta tierra de altura por las noches tiembla el rocio. En los amaneceres la yerba sube hasta el corazón conducida por el aroma. En los días grises de lluvia pertinaz, de pertinaz lluvia menuda, la nostalgia desborda los recuerdos. En los días soleados, calientes al mediodía, el corazón desea galopar libre de uno a otto confín."

El valor de La ciudad y el viento reside en el interés que no decae, en la posición objetiva del autor y en la técnica nueva - desde Dostoievsky hasta Joyce y los modernos- por el cual hoy, como ayer García Márquez y como Zapata Olivella, se va situando Colombia en la novelística contemporánea. Airó no improvisa. Su novela es obra de varios años de estudio y de trabajo. Ha perfeccionado la técnica de su novela Sombras al sol (1951). Trabajó fichas separadas para cada personaje y fichas especiales para la ciudad. La ordenación y colocación le llevó mucho tiempo. Tuvo el cuidado de que las palabras dieran una clave en el reencuentro de los personajes. Cualquiera página suscita el interés. La corriente de conciencia sitúa la acción por dentro y allí se va desenvolviendo. Esa acción va entremezclada con sentimientos y pensamientos, con descripción de ambiente. La letra bastardilla va señalando la intimidad de cada yo. Hay descripción e introspección, narración de dentro hacia afuera. $\mathrm{Y}$ esta técnica, que a primera vista puede parecer confusa, está realizada con tal maestría que llega a la claridad. Cuando en este desarrollo por planos se corta la acción hacia otro personaje, el interés se va acumulando gradualmente. Son muchas historias en una sola; el lector va tomando una y otra hasta llegar a igualarlas a veces, hasta llegar a diferenciarlas. Todas terminan en algo, llegan a algo.

Hay pensamientos claves: "... pensó magnánimo si ese despliegue total de sexo, aquella obseción por el sexo, aquel dominio del sexo en la vida actual no sería en el fondo sino una sapiente fuerza vital, una afirmación del inconsciente colectivo para salvar la vida del hombre cuando la ciencia, esa ciencia atrapada por los regímenes del poder, ponía instrumentos de destrucción total", dice Carlos Camacho (p. 348). Y Leonor: "Hartas consideraciones con una, si una está arriba, triunfante, si una tiene influencia. ¡Ah, si una tuviera apellidos entonces tendría todos los privilegios. Este país es asi" (p. 180). Y Vicente: "La gente educada se pone de acuerdo para ser imbécil, para vivir $y$ enriquecerse respaldada por las instituciones intocables.

Conozco esas instituciones y los hombres que las manejan, sí conozco a esos hombres. ¡Sí los conozco. Son idiotas atrincherados en grandes insignias, en grandes frases, en lápidas de mármol" (p. 199). Y Carlos Camacho: "La historia de la cultura podría llamarse también la historia de los triunfos de la 
verdad" (p. 341). "El amor es la verdad. He aquí porque la gran aventura del hombre puede llamarse también la gran aventura del mor". (p. 348). Y el Chivo: "Entonces era bello vivir. La ciudad acababa allí mismito -volvió a lanzar el brazo hacia el norte- si, junto a la iglesita de San Vicente. Se iba de paseo en elegantes coches de caballos... iAh aquellos tiempos! En cambio ahora, doctor, todos ladrones, todos a tirarse al vecino..." (p. 293).

La más honda emoción hace surco en la escena de Vicente, borracho, entregando el regalo a Leonor. Allí se supera el novelista. Vicente, tembloroso, balanceándose, llega a una hora imprevista; Leonor, espera una de tantas tormentas. "Y abrió el estuche. Un anillo de oro con esmeralda surgió tentador. -Es para tí, para tí... toma, dijo tembloroso, con miedo, sumiso. Leonor continuó inmóvil, el corazón comenzó a latir con violencia - Por eso viene a estas horas Es nuestro aniversario de bodas... siempre me acuerdo, siempre, todos los años." (p. 102).

Al borde de la catástrofe, en una vida sin remisión, queda brillando una esmeralda.

La poesía cruza la novela de punta a punta, dice Clemente Airó. La descripción de la ciudad es, para !l, verso puesto en prosa:

La borrasca de la tarde recomenzó con parecida furia hacia las doce. Los desgarrones de los relámpagos cruzaron incesantes de oriente a occidente. La ciudad quedó desierta, azotada por las inclemencias del tiempo. La humedad penetrante estremeció los huesos de los vigilantes nocturnos. Nieblas acuosas posaron alrededor de los faroles. De cuando en cuando el tañido de la campana de algún reloj. En los barrios pobres, en las mis!rrimas casuchas de los arrabales se escucharon plegarias, mientras niños, mujeres, hombres y los equipos de salvamento, lucharon infructuosamente contra la crecida de las aguas que iba arrasando los modestos hogares ( $p .117$ ).

No es necesario dar más explicaciones. Clemente Airó se ha consagrado como novelista colombiano, hispanoamericano, con una obra que puede competir con las mejores del género.

Instituto Caro y Cuerio,

Cecilia Hẹrnández de Mendoza. Bogotá, Colombia.

Alfredo A. Roggiano, Pedro Henriquez Ureña en los Estados Unidos. State University of Iowa Studies in Spanish Language and Literature, Vol. 12. México: Editorial Cultura, 1961.

A principios de este siglo llegaron a Nueva York, procedentes de Santo Domingo, los hermanos Francisco, Pedro y Max Henríquez Ureña, hijos del 
eminente médico Francisco Henríquez y Carvajal, poco después presidente de la República Dominicana, y de la famosa poetisa y educadora Salomé Ureña de Henríquez. Venían, dice Pedro, para recibir los beneficios de una cultura supefior. Muchos jóvenes de Hispanoamérica viajan al extetior para completar así su educación, y logran poco. No es el caso de los hermanos. Henríquez Ureña, especialmente Pedro y Max, quienes supieron aprovechar todo lo que la vida neoyorquina les ofrecia en sus teatros, conciertos, museos, conferencias, universidades, etc. La vida que llevaron fue tan activa y rica en detalles culturales, que Pedro, en unas "Memorias" que el profesor Roggiano da a conocer por primera vez, nos ha dejado un valioso documento, no sólo personal, sino de la época y el ambiente que frecuentó.

De Nueva York Pedro Hernández Ureña pasó a Cuba y poco después a México; así participó en la vida intelectual de ambas repúblicas. Durante la Revolución Mexicana, por acontecimientos que afectaron la vida interna de dicho país, Pedro regresó a Estados Unidos. Durante cinco años fue estudiante y profesor en la Universidad de Minnesota, donde, además de promover un activo movimiento en favor de las letras hispánicas, obtuvo el título de doctor, con una tesis que le ganó un prestigio excepcional entre los especialistas de la literatura española. Llamado por José Vasconcelos, Ministro de Educación de México, volvió a la tierra de Juárez para ocupar altos puestos en la Universidad y la Secretaría de Educación. Dos años después fue a la Argentina, donde residió hasta su muerte, en 1946, consagrado a la enseñanza, tareas editoriales, conferencias, etc. Durante el año académico de 1940-1941, hizo su tercer viaje a los Estados Unidos, invitado por la Universidad de Harvard para ocupar la cátedra de Poética "Charles Eliot Norton", en la que desarrolló un curso magistral sobre la literatura latinoamericana publicado primero en inglés por dicha Universidad y traducido en México con el título de Las corrientes literarias en la América bispánica.

El libro del profesor Alfredo A. Roggiano llena un gran vacío en los estudios hispánicos en Norteamérica, ya que documenta en forma precisa estas tres temporadas en que don Pedro vivió en los Estados Unidos y nos permite seguir su formación durante esas visitas. Además de un documentado prólogo, el libro incluye escritos periodísticos y eruditos publicados por el maestro dominicano. Debemos agradecer al profesor Roggiano, sobre todo, su labor en el archivo universitario de Minnesota. Don Pedro se habia disciplinado antes de llegar a aquella institución, especialmente en la capital mexicana, cuando colaboró intensamente en el Ateneo de la Juventud; pero demostró su madurez al lograr su doctorado durante menos de tres años de estudios en la Universidad norteamericana, con su famosa tesis sobre la versificación irregular en castellano.

La vida de don Pedro en Minnesota fue ejemplar. Fomentó la cultura hispánica en el Estado y ensanchó la colección latinoamericana de la Biblioteca universitaria. Reconoció el aporte de los Estados Unidos a los estudios del castellano y de la cultura lationamericana aún mientras vivía en Washington. Compara el sistema universitario francés y latino con el sajón y critica con perspicacia la especialización de éste, que permite al alumno seguir materias escogidas libremente. 
Los escritos incluidos en este tomo empiezan con los artículos que redactó en Washington al comienzo de la primera guerra mundial, mientras servía como corresponsal de El Heraldo de Cuba, muchos firmados con el seudónimo de E. P. Garduño. Había llegado de México, empapado del espíritu de su Revolución, a la que supo valorat en su alto significado; sus observaciones sobre la vida mexicana nos dan una sensación de presenciar cosa vivida. Discurte sobre el movimiento feminista, los asuntos latinoamericanos, la política interna y externa de los Estados Unidos, y poetas y anigos como Thomas Walsh, el nicaragüense Salomón de la Selva y el filósofo y sociólogo Antonio Caso. Sus mejores pensamientos están en español, cosa que no comprendían los periodistas de Minneápolis cuando lo intetrogaban acerca del papel de su distinguido padre en la presidencia dominicana; pero hay algunos redactados en inglés, sobre todo para el público de Minnesota. Los ensayos más dignos de conservarse y quizás incluir en las antologías futuras son los que escribió después de la muerte de Rubén Darío en 1916, y su clásico análisis del español dominicano para defenderlo contra la opinión superficial del filólogo romanista Meyer-Lübke.

Felicitamos sinceramente al profesor Roggiano y a la Universidad del Estado de Iowa por la publicación de este trabajo biográfico sobre unos de los mejores críticos que han nacido en este continente, presentado en una de sus etapas menos conocida: la de su labor docente y desarrollo intelectual en los Estados Unidos. Necesitamos ahora un libro similar sobre la obra de don Pedro Henríquez Ureña en México (sabemos que el profesot Roggiano lo tiene ya casi listo) porque llevó una labor cultural muy intensa en la hermana repíblica; y quizás un tercero sobre su época culminante en Buenos Aires. Hace falta un índice de materias y de personas, que se podría agregar en una edición posterior.

University of Minnesota

T. B. IRVING

Othon Castili.o, Sed en el puevto. México: Ediciones de Andrea, 1962.

La novela ecuatoriana ha hecho un largo recorrido, desde la peripecia romántica de Juan León Mera - cuya Cumandá, por cierto, guarda curiosas coincidencias de asunto con Cecilia Valdés, del cubano Cirilo Villaverde- hasta los nuevos narradores orientados hacia problemas estructurales, sociales, enriqueciéndose con nombres y obras que van a desmentir la afirmación del Conde de Keysserling dicha en sus Meditaciones Sudamericanas y divulgada luego por el profesor Pedro Grasses--; afrimación que modernamente puede enunciatse asi: "Europa novela la historia; América, la geografia".

En verdad que hay todo un ciclo - y de los muy principales- en muestra novelística, en el cual el solo estímulo literario parece ser el ámbito geográfico, el contorno agresivo del medio natural. La naturaleza actúa con fuerza protagónica en clásicos como Camandá, La Voragine, Canaina, Doña Bárbara, y otros. Pero traspuestas estas etapas razonables del "descubrimiento" y la "con- 
quista", la literatura hispanoamericana parece orientarse cada vez más hacia zonas más ecuménicas, donde la familia humana, con sus peripecias y afanes, es principio y término. A este impulso nuevo corresponde la novela con la cual el escritor Othón Castillo inicia su diálogo con los lectores.

Sed en el puerto es el relato de todo un pueblo que languidece por falta de agua, a orillas del mar; está contado en la tercera persona. $Y$ si al principio nos produce extrañeza la falta de un héroe, de un carácter fuerte que concentre el fluir, el dinamismo de la trama, que la haga necesaria, más adelante entendemos que las intenciones del autor fueron justamente las de saltar de uno a otro protagonista, mostrando como sujeto de esta acción al pueblo todo. Sus primeras páginas traen un relato, la vida, pasión y muerte de Pedro Meto. El pescador luchando con un tiburón, arrastrado por éste mar adentro, combatiendo de igual a igual, recuerda el cuento de Hemingway. $\mathrm{Y}$ es probable que Castillo -más, es seguro- escribiera este libro antes que el barbudo suicida, su nouvelle. Porque Sed en el puerto pertenece a esas novelas rescatadas del baúl donde duermen los trabajos literarios de tantos escritores. Esta, rescatada con razón, que muchos baúles son severos críticos. $\mathrm{Y}$ según nos dijera el autor, fue escrita illo tempore.

Clérigos, profesores, funcionarios administrativos, jefes de policia, pescadores, aventureros, mujeres, hombtes, niños del pueblo ecuatoriano, todos se concentran aquí, en estas doscientas páginas de relato ágil, nervioso, rápido, que lleva al lector de la entretención a la meditación, haciéndolo avanzar por este mundo cruel, lleno de pasiones bajas y altas, árido, agobiante, en su desesperanza. Castillo escribe con economia de expresión, sin raptos líricos que tantos ripios dan a la prosa de algunos ilustres novelistas hispanoamericanos, conteniendo la frase, sometiéndola al autor, funcionalizándola estrictamente. Su adjetivación es certera. Elude la metáfora colocando sólo aquéllas indispensables a la variedad de la prosa. El diálogo, en que abunda la obra, está bien desarrollado; el autor establece niveles psicológicos de los protagonistas y fluidez coloquial. No abusa de voces dialectales, que hagan del glosario final una clave para seguir la lectura.

La figura de Tan-Tan, un carácter desarrollado sólo en los últimos capitulos del libro, parece crecer inesperadamente, con vías a quitar papel protagónico al pueblo todo, para asumirlo él solo, con sus peripecias, como redentor social. Pero Castillo no insiste demasiado en el personaje, o lo trabaja muy tarde, y su breve liderazgo aparece algo esquemático. El libro abunda en escenas violentas, torturas, muerte, sexo. El punto de vista del autor —su mejor acierto- es el de un espectador, de simple espejo que refleja la realidad, aunque elegida y seleccionada con visible voluntad de estilo y de tema. No hay opiniones, sino aquellas que se desprenden de los hechos mismos.

Othón Castillo es escritor naturalmente dotado. Avanza sin esfuerzo, sin que se sientan detrás de la ficción, los padeos y transpiraciones del estilista. Su materia es veraz, transparente. Carece de impostaciones culteranas. $Y$ esta primera obra, por tales determinaciones, le da un lugar y un deber entre los escritores ecuatorianos contemporáneos. El lugar, en las primeras filas. El deber, seguir desplegando el universo de su experiencia viva, en tareas cada vez más 
experimentales y auténticas, exigiéndose a sí mismo su más alto nivel de rendimiento creador.

\section{Universidad de Chile}

\section{ENRIQUe LAFOURCADE}

Carlos Fuentes, La muerte de Artemio Cruz. México-Buenos Aires: Fondo de Cultura Económica. [Colección popular No. 34], 1962.

La personalidad literaria de Carlos Fuentes es bien conocida, dentro y fuera del país, desde la publicación de una selección de cuentos, Los dias enmascarados, en 1954. Posteriormente a esta fecha, su actividad en el periodismo literario y en el político, y la aparición de su primera novela, La región más transparente (1958), afrimaron sus valores de escritor talentoso, inconforme, y muy dueño de sus recursos. Esta su primera novela desconcertó por su indudable novedad. Se advertía de inmediato que el autor estaba en desacuerdo con los buceos en la miseria y en la sordidez, en la degeneración y en el vicio, y en los desajustes sociales en que otros escritores se detenían para protestar en contra de la desintegración de valores que padecemos, exhibiendo con intencionado realismo todas las llagas y la podredumbre, pero supeditando la intención estética al valor documental histórico, sociológico, o psicológico. Fuentes, en La región. .., pretendió integrar en una sola visión, todo el mundo inmaduro, contrastado, dividido, artificioso, dramático, inconsistente que es la ciudad de México, hoy, con intención totalizadora y trascendente. Para lograr este "fotomontaje" de tan ambiciosa perspectiva, elaboró cada pieza en función del todo, pero cuidando de que el tratamiento de recreación se acomodara al tema, le diera su personalidad propia y se justificara en el conjunto por relaciones comunes. Si la meta es dar una idea integral y monumental de nuestra realidad, tendrán que ser los procedimientos técnicos los que mantengan el equilibrio estructural de la novela. Y es ahí donde Fuentes muestra su segura habilidad. Tanto los sistemas tradicionales del Diablo Cojuelo como las más modernas audacias de los mejores novelistas del mundo, se combinan con eficacia para darnos una de las novelas más inquietantes de nuestro tiempo.

Las buenas conciencias (1959), primera parte de una trilogía de novelas que no ha llegado a aparecer, no desmiente la promesa del joven novelista que se inició en La región. ., antes bien da otra faceta - la opuesta - de su capacidad creadora, en tanto que Aura (1962), novelita que rebasa las realizaciones de Los días enmascarados, es una visión más elaborada de un mundo fantástico dominado por la personalidad de una vieja enajenada que curiosamente se asoma como la clave secreta del pasado, en varios libros de Fuentes.

La muerte de Artemio Cruz (1962) narra las doce horas de agonía del personaje central, en las que aflora su pasado en relación con los días que supuso definitivos en su vida. Artemio Cruz, de origen oscuro, participa en las luchas de la Revolución y logra convertirse en uno de tantos "hombres fuertes", cuya 
voluntad es ley y cuyo oro todo lo compra. La muerte de Artemio Cruz continúa, en cierto modo, las preocupaciones que Fuentes habia enfrentado en La región.... Sólo que ahora va a exponer medio siglo de la vida de México, pero a través de la conciencia de un hombre y precisamente de uno que ha sufrido en si mismo las transformaciones del país, y en el momento en que éstá desnudo y sin máscara frente a la muerte. En las dos novelas el asunto central es la búsqueda de la verdad en la vida de México, con atención especial en la clase que domina en estos momentos, recordando que "Ios nuevos ricos de hoy serán la aristocracia de mañana, como la aristocracia de hoy fueron los nuevos ricos de ayer". Y la duda dolorosa de si a un país como éste, tan cargado de experiencias confusas, le será posible escoger su propio camino.

Por muchas razones La muerte de Artemio Cruz debe considerarse como un adelanto en la brillante carrera de novelista de Fuentes. Al alarde técnico de manejar tantos recursos estilisticos, ha preferido encauzar y fortalecer los que pro. vienen naturalmente de la situación de los personajes $\mathrm{y}$ de la necesidad de la acción. La unidad, a ratos tan artificial en la primera novela encomendada al personaje simbólico, Ixca Cienfuegos, es más real y efectiva en la segunda, puesto que Artemio Cruz es quien determina tanto sus actos propios como los de los otros personajes. Al estatismo de los cuadros que se superponen y se multiplican en La región... ha sucedido el dinamismo interno, creador, vigoroso, audaz. $Y$ a aquel pesimismo total que se determinaba desde los orígenes, en ese ser y estar en este lugar, en esta tierra, sin claridad ni "transparencia" sólo porque nos tocó irremediablemente ... se opone ahora la afirmación por el amor; por la libertad de amar, proyectada a través de toda la vida y sobre los odios y la muerte.

Quizá el oficio y la personalidad más íntima de Fuentes escritor se vea con más justeza en los elementos que se conservaron de una novela a otra y en la última se reafirmaron y enriquecieron. Si desde el primer momento se había manifestado como creador de ambientes, conocedor de todos los rostros de la ciudad, sus tipos característicos, su lenguaje o su clave de comunicación, su mediocridad, sus imposturas, su gracia, su ingenuidad, sus dramas reales e inventados, etc., la evolución del personaje central, Artemio Cruz, va dando ocasión, gradualmente, a enriquecer la experiencia del hombre, a explicar sus cambios, sus contradicciones, sus fracasos, a través de distintas circunstancias. Su nacimiento en una choza de negros; su infancia solitaria, rechazada de la casa grande, compartiendo la miseria y la escondida ternura del pobre Lunero; después, la vida dura y las circunstancias favorables. $Y$ de aquí, el camino sin ley y sin escrúpulos para llegar a la riqueza y al poder. La adulación y el servilismo cooperan y favorecen la entronización de estos ejemplares, y la sociedad que los toleró soporta, humillada, la vejación de sus instituciones $\mathrm{y}$ de sus principios. Artemio Cruz es el símbolo de estos hombres primitivos que logran el dominio, lo disfrutan, aunque alguna vez lo más anhelado se les escape de las manos. El lenguaje fresco y directo, recorre también, comó los temas, todas las gamas de un registro ilimitado en el cual se pretende la libertad; por ello la poesía y las blasfemias ocupan su sitio real, y lo sentimental se esquiva como una salida torpe y decadente. No hay compasión ni fe, ni escrúpulos ni limitaciones 
en la expresión aguda, abrumadora de inhumana frialdad. A veces una apretada sintesis de antecedentes informa de ciertas circunstancias y el tono exaltado de algunas páginas lleva implícita una protesta o una crítica punzante y agria. La impresión final es de que el material con que Fuentes trabaja sus novelas será inagotable, manejado por su talento y proyectado hacia todos los rumbos de nuestra realidad social, donde su afán crítico y su sensibilidad creadora encuentre puntos de interés.

Universidad Nacional

María del Carmen MilláN

Autónoma de México

Carmen Olga BRenes, El sentimiento demoriático en el teatro de Juan Ruiz de Alarcón. Valencia: Editorial Castalia, 1960.

La interesante obra que nos ocupa aporta nuevos puntos de vista en los estudios del gran dramaturgo mexicano, y en nuestra opinión este trabajo se coloca permanentemente junto al de los críticos que con éxito se han ocupado del teatro de Juan Ruiz de Alarcón. Sin embargo, debemos señalar que el estudio de la señorita Brenes no posee la misma calidad en todos sus capítulos. La segunda parte, en la que se hace un cuidadoso análisis de la comedia alarconiana y en la que el texto y el espíritu del creador de caracteres son interpretados con aguda visión, nos parece una contribución valiosa.

El libro de la señorita Brenes está dividido en tres partes: la primera (pp. 9-81) trata de "Consideraciones preliminares" y está a su vez dividida en tres capitulos: "I. Introducción." (pp. 9-12), "II. Desarrollo del sentimiento democrático del pueblo español." (pp. 13-44) y "III. Aspectos del sentimiento demorático en el Siglo de Oro." (pp. 45-81).

La segunda parte está dividida en seis capítulos: "IV. El concepto de la dignidad humana en Alarcón." (pp. 85-116), "V. El concepto de la nobleza en Alarcón." (pp. 117-133), "VI. El concepto del criado en Alarcón." (pp. 134-184), "VII. El concepto del mérito en Alarcón." (pp. 185-199), "VIII. El concepto de la justicia en Alarcón." (pp. 200-221), y "IX. Contradicciones aparentes en el sentimiento democrático alarconiano." (pp. 222-234).

La tercera parte lleva como encabezado "Conclusión" y está dividida en tres capitulos: "X. La obra de Alarcón dentro de la tradición democrática de la comedia del Siglo de Oro." (pp. 237-242). "XI. Singularidad del sentimiento democrático alarconiano." (pp. 243-251), y "XII. Resumen" (pp. 252-259). El libro termina con "Bibliografía" (pp. 261-269), "Apéndice." (pp. 271-276) y "Traducciones." (pp. 277-278).

La autora explica que al tratar del "sentimiento democrático español" no se refiere a "un concepto de base política, sino a un singular sentimiento de base humana que brota del concepto de la igualdad basada en la dignidad del hombre como poseedor de un alma inmortal, sin distinción de casta ni posición social." (p. 10). 
La obra que nos ocupa pasa luego a analizar el desarrollo de este sentimiento en algunos rasgoș étnicos, hechos históricos, leyes, costumbres tradicionales, principios religiosos y algunos pasajes literarios anteriores al Siglo de Oro. Los ejemplos que cita la señorita Brenes son bien conocidos, y con ellos elabora su punto de vista, aunque nos parece que era necesario haber hecho salvedades, pues en la realidad no ocurría como ligeramente apunta la autora, por ejemplo, al fundamentar en la religión lo que ella considera sentimiento democrático: "De la doctrina católica aprende el español que todos somos hijos de Dios, que todos tenemos un alma inmortal que iguala al rico y al pobre, al humilde $y$ al pode. roso." (p. 30). Tampoco los casos de la literatura que cita pueden tomarse como lo general sino como lo excepcional, como en efecto lo fueron Mio Cid (p. 33), personaje literario que es, además, diferente al Rodrigo histórico, Hernán Cortés (p. 34), el Arcipreste de Talavera (p. 35), el de Hita (p. 35), y Juan del Encina (p. 36), a los que toma como ejemplos al tratar del "popularismo" (pp. 32-36). Nuestras reservas son más serias con estos dos últimos, pues si una parte de la obra de ellos contiene indudablemente "popularismo", éste es, en el caso del arcipreste Juan Ruiz, sólo uno entre otros más importantes ingredientes de su Libro, verdadera enciclopedia medieval, y en el caso de Encina lo popular es lo menos característico de su poesía y de su teatro, productos del humanismo renacentista y de su vida en las cortes. Podrían disculparse estas ligerezas ya que parece que la autora se dejó llevar por insubstanciales observaciones generales, como las que a menudo cita de las historias de la literatura de Angel del Río y de Valbuena Prat, a los que parece otorgar la autoridad de quienes tienen la última palabra (pp. 33, 35, 39, 58, 64, 67, 69, 71, 73, 75, 84, 180, 195, 231, $242,246,248)$. Otras obras generales que también cita a menudo son las de Pfandl (pp. 29, 36, 47, 49, 51, 55, 58, 64, 68, 70, 78, 87, 135, 146, 160; 177,222 ) y en menor grado, afortunadamente, las de Montoliu (pp. 53, 59), Barja (pp. 88, 192) y Brennan (p. 58). Sin embargo, de la bibliografía nos ocuparemos al final. En las páginas que ahora comentamos se aprecia claramente lo que arriba señalamos: "En su Historia de la literatura española, nos dice Angel del Río que: «...lo popular... Se encuentra también en el espíritu democrático - de base humana no política- que corre desde el Cantar de Mío Cid..." (p. 33). Por lo que respecta al creador de los pastores ideales y fervientes gentiles Fileno, Victoriano, Justino, Cristina y Plácida, sin olvidarnos de la verdadera inspiración costumbrista de su Auto del repelón, no nos parece justificada la apreciación que de él se hace en las páginas que nos ocupan: "Y Juan de la Encina recoge la frescura y vitalidad de lo popular en sus églogas, con lo cual tenemos la primera nota democrática en el teatro español." (p. 36) Señalemos también que aquí como en otras páginas del libro, hemos tenido la impresión de que el término "democrático" se usa de manera sumamente lata.

En el capítulo III se estudia el sentimiento democrático en el Siglo de Oro en la sociedad de los Austrias y en la comedia. De esta manifestación literaria cita algunos títulos de comedias de Lope de Vega inspiradas en leyendas, romances y cantares de la lírica popular. A éstos se añaden títulos de comedias de Guillén de Castro, Vélez de Guevara, Cubillo, Tirso, Cervantes y Rojas Zo. rrilla en las que el elemento popular tiene importancia. Esta parte nos parece 
débil por no entrar en detalles y por tratar globalmente las obras de autores tan desemejantes. Está mejor desarrollado el final de este capítulo que trata del "honor plebeyo" (pp. 70-74), "la justicia real (pp. 74-77) y el "sentimiento de igualdad" (pp. 77-81).

La Segunda Parte del libro que reseñamos se ocupa de analizar el sentimiento democrático en el teatro alarconiano y es, repetimos, una valiosa aportación al estudio del insigne mexicano. Del capítulo IV, que trata del concepto de la dignidad humana en el dramaturgo novo hispano, son estas acertadas observaciones: "Juan Ruiz de Alarcón no coincide con los dramaturgos coetáneos en su concepto de la moral. Esta es, en su teatro, natural en el hombre y deriva de virtud íntima." (p. 86). Lo anterior, basado en conocidas apreciaciones de Américo Castro, lo contrasta la autora con la moral escolástica de otros dramaturgos, y luego, apoyándose en Menéndez Pidal (De Cervantes y Lope de Vega), asienta que el concepto del honor como virtud íntima se encontraba en autores anteriores y contemporáneos a Alarcón, y refiriéndose nuevamente al teatro, observa que en "la comedia clásica, con la excepción de la alarconiana, el honor se convierte en la opinión, en la estimación que del individuo tienen los demás, depende de actos externos y no de la virtud íntima." (p. 88). Esta aserción de la señorita Brenes no deja de tener validez, pero también aquí es necesario hacer hincapié en el hecho de que no sólo Lope de Vega sino hasta dramaturgos como Calderón o Rojas Zorrilla, que son quienes más se distinguen en el exagerado tratamiento de la puntillosa fama como sinónimo de honor, tienen en su haber comedias en las que también se apunta la idea de que el honor es patrimonio de la intimidad virtuosa del alma y en las que protestan contra el bárbaro código. Por ello resulta peligroso en la comedia hacer declaraciones absolutas, como la que sigue a la anterior, en que, al exponer estas dos actitudes o doctrinas de la honra, afirma categóricamente que. "Alarcón es el único de los dramaturgos del Siglo de Oro cuya obra refleja la otra [intima] corriente de pensamiento." (p. 88). Es evidente que la señorita Brenes tiene razón en parte y que su entusiasmo por la obra del insinge mexicano la lleva a estas afirmaciones.

Señalemos, por otra parte, esta valiosa crítica: al parafrasear una observación de Menéndez Pelayo (Historia de la poesia bispanoamericana, I, p. 64) respecto a la moral caballeresca en el teatro de Alarcón, la autora agrega significativamente: "no es, sin embargo, la moral heroica, al alcance sólo de individuos de una clase privilegiada." (p. 90), y redondea su pensamiento añadiendo que "la suya es una moral laica a cuya formación debieron contribuir sus estudios humanísticos y quizás su profesión... Tal vèz al hecho de que en Alarcón el moralista deriva del jurista y no del teólogo se deba el que sus virtudes no sean las heroicas, que llevan a la santidad, sino las laicas al alcance de todas las almas." (p. 91) y con esta premisa, que hace eco a ciertas observaciones de Alfonso Reyes, de Henríquez Ureña y de Castro Leal, la señorita Brenes selecciona numerosos versos de la comedia alarconiana en los que se ilustra la moral del famoso corcovado sobre vicios y virtudes (pp. 91-105). El capítulo termina con un estudio en el que la señorita Brenes demuestra con ejemplos abundantes que para Alarcón la virtud es el mayor bien, y lo cierra con una glosa de lo apuntado por Antonio Castro Leal [Juan Ruiz de Alarcón, Su vida y su obra 
pp. 189-90), respecto a la distinción entre el heroísmo común, que es impuesto al individuo desde afuera, "y el que impone la propia virtud, que tiene sus raices en el ser mismo, en la que podemos llamar la bidalguía original." (p. 110). En la elaboración de esta idea la investigadora escoge como ejemplos para ilustrarla No bay mal.... . Todo es ventura, Las paredes oyen, Los favores del mundo, etc., concluyendo que "el concepto que tiene Alarcón de la dignidad humana está basado en su concepto de la moral. Para el autor, la moral nace de la intima virtud, de la que dicta la conciencia, no las convenciones sociales. El honor es un atributo de la virtud y no lo dan ni quitan circunstancias externas. Sólo la virtud puede dar honra. Las virtudes que la dan y los vicios que la quitan, no son los heroicos, sino los que se hallan al alcance de cualquier hombre, $\mathrm{y}$, así, el honor no es privilegio de clase." (p. 116). Objetaríamos aquí; como en otros pasajes, no a la idea que quiere expresar la autora, sino a las palabras que escoge para hacerlo; así, en la última parte de lo arriba trascrito a uno se le ocurre preguntarse qué quiso decir por "vicios heroicos", ¿acaso debemos leer antiheroicos? Suponemos que quiso referirse a lo grande y propio de los héroes tradicionales, es decir, los gigantes entre los hombres tanto en lo bueno como en lo malo: mártires, santos, guerreros, reyes, traidores, perversos, etc., y que las virtudes y los vicios "que se hallan al alcance de cualquier hombre" no excluyen de cualquier hombre lo grande y excepcional, en lo bueno o lo malo. Creemos que la señorita Brenes se refiere con "al alcance de cualquier hombre" a situaciones cotidianas y corrientes en las que prueba moralmente el hombre. Este abaratamiento de la moral con la frase "al alcance de cualquier hombre" se encuentra reiterativamente en el libro.

El capítulo $\mathrm{V}$ trata del concepto de la nobleza en Alarcón y está dividido en dos partes; en la primera se comprueba con bien seleccionados ejemplos que "para Alarcón, es un concepto que se predica sólo del alma y no de la estitpe. Entiende la nobleza en el sentido moderno, en el de cualidades morales." (pp. 117-118). En la segunda parte, después de referirse a observaciones de Julio Jiménez Rueda (Juan Ruiz de Alarcón y su tiempo) respecto a que "En los reinados de los últimos Austrias la grandeza de España va dando lugar a una nobleza cortesana, derrochadora, fatua" ( $p$. 125), la señorita Brenes afirma que esta nobleza "es el blanco de la sátira de Alarcón, para quien la virtud intima es la única nobleza." (p. 125). Nuestra autora saca sus ejemplos de parlamentos de nobles, cortesanos y graciosos, y respecto de estos últimos hace una atinada ecuación: "Gracián se valió de símbolos alegóricos; Quevedo, de sueños, y Cervantes puso la sabiduría en boca de locos y de perros. La sabiduria en boca del gracioso es el medio del cual se vale la comedia del Siglo de Oro. Siguiendo la costumbre, Alarcón, por medio del gracioso, saca [sic] la sátira que censura los defectos de los nobles de su tiempo." (p. 126). El personaje del gracioso es extensamente estudiado en el capítulo siguiente: "El concepto del criado en Alarcón" (pp. 134-148), y después de exponer algunas ideas sobre el gracioso de la comedia en general, la señorita Brenes trata acerca de una aceptada característica del teatro alarconiano que después elabora con numerosos y variados ejemplos: "El criado Alarcón no es el criado convencional, picaresco, vulgar, antiheroico. Tal vez porque en la servidumbre Alarcón se ve a sí mismo, sabe 
comprender y estimar al que sirve y darle dignidad. Sus criados no apoyan la manera de pensar del pueblo, ni es su moral groseramente realista, ni son sus bromas plebeyas. El autor ennoblece al criado y eleva su condición porque, para él, el servir o ser servido es sólo distancia de fortuna y no de naturaleza." (p. 136). Esta última idea es casi una paráfrasis del pasaje de Ganar amigos, citado a continuación por la señorita Brenes, la cual concluye esta valiosa parte de su capítulo rindiendo homenaje al fallecido erudito mexicano $\mathrm{Ji}$ ménez Rueda al citar una página de su Juan Ruiz de Alarcón y su tiempo (p. 221), en la que definitivamente quedó asentada la contribución alarconiana en la "dignificación del criado." (p. 158). En la segunda parte de este largo e interesante capitulo sobre las relaciones entre amo y criado, la señorita Brenes concluye que éstas "son democráticas: el criado es consejero, guía y amigo de su amo, más bien que sirviente... Los galanes y las damas no guardan secretos para sus criados en cuya prudencia y cautela tienen completa fe, y éstos son fieles y leales a sus amos, se preocupan por su felicidad y velan por su honor." (p. 184). Fn cuanto a esto último*creemos pertinente señalar que Rojas Zorrilla no echó en saco roto la contribución alarconiana a la comedia.

En el capítulo siguiente (VII, "El concepto del mérito") nos parece que nuestra autora, llevada por el entusiasmo de su tesis, confunde términos y significados, pues lo que aquí ella considera democracia nos parecería mejor calificarlo como justicia: "Una de las notas democráticas más marcadas en el teatro de Alarcón es su concepto del mérito. Creía que sólo debe alcanzar el que merece." (p. 185). Haciendo a un lado la objeción anterior, debemos apuntar que la señorita Brenes señala con bien seleccionados ejemplos la parte que tienen en el logro del favor la suerte, el agrado y el soborno. (pp. 187-192). En la segunda parte del capítulo, nuestra autor demuestra que Alarcón premia la virtud y el mérito personales por encima de cualquier otra consideración. Bajo otros aspectos se persigue este tema en el capítulo siguiente (VIII, pp. 200-221), el cual lleva como encabezado "El concepto de la justicia en Alarcón" y está dividido en tres secciones: la justicia real, que engloba las obligaciones del vasallo y del rey. Cuando éste "se olvida de sus magnas responsabilidades y obligaciones y no se conduce como quien es, el vasallo tiene el derecho de llamar la atención al soberano y de afearle su conducta." (pp. 207-208). La segunda sección trata de "la preocupación por el mejoramiento de las leyes" y la tercera, sobre "los derechos del pueblo." A pesar de que nuestra autora sostenga que "a los dramaturgos del Siglo de Oro que llevan al teatro el concepto democrático del derecho del villano a la venganza del honor, aun cuando para realizarla haya que dar muerte a un noble, ha de añadirse el nombre de Juan Ruiz de Alarcón." (p. 221), tenemos que hacer otro reparo, porque no es por allí por donde se encontraría la valiosa aportación original del dramaturgo urbanista a la comedia. Ningún autor, en nuestra opinión, iguala a Lope en la frescura y el sabor a tierra de sus villanos, y en el caso que nos ocupa, la señorita Brenes reconoce que en los dos ejemplos que estudia (El tejedor de Segovia y El dueño de las estrellas) bajo el disfraz de villanos se ocultan "el caballero don Fernando Ramírez" (p. 220) y el "sabio Licurgo" (p. 221), respectivamente. Claro que la venganza es ejecutada en ropa villanesca, lo cual convenimos que no deja de ser significativo, pero nuestra objeción no estriba en esto, 
sino en "añadir el nombre" del por otra parte insigne creador de caracteres morales junto a los de Lope o Vélez de Guevara, pero ni siquiera a los de Calderón o Rojas Zorrilla, en lo que respecta a yillanos que vengan su honor.

El caṕtulo IX (pp. 222-234), último de esta segunda parte, es, a pesar de su encaberado: "Contradicciones aparentes en el sentimiento democrático alarconiano", un resumen de cada uno de los capítulos precedentes, y a menudo nuestra autora nos refiere a ellos. En general, es una buena tecapitulación y la șeñorita Brenes lo subdivide en lo que ella considera "lo externo": el realismo, los cuadros de costumbre caballeresca, el ambiente cortesano, la "ley de caballero", y, el disgústo por la corte y los señores; la segunda subdivisión es "el fondo", en la que trata la moral de caballeros, el sentimiento monárquico, y, el sentimiento de igualdad. La tercera subdivisión es la "conclusión". En esta recapitulación encontramos, como en casos anteriormente señalados, cierta confusión de términos. Por ejemplo, a pesar del encabezado, no hemos logrado encontrar las "Contradicciones aparentes en el sentimiento democrático alarconiano" que se nos anunciaron; sí indica la autora que "en toda la obra de Alarcón he encontrado sólo un pasaje que es una contradicción del sentimiento democrático que abunda en ella." (p. 233), y cita un pasaje del gracioso Zaratán de La crueldad por el bonor. Pero, después de releetlo hemos advertido que no hay contradicción, sino conformidad con el pen. samiento alarconiano que la señorita Brenes analiza en el capítulo sobre el con. cepto del mérito (VII), y en particular en la subdivisión de "protesta contra el favor", porque aquí tenemos también, nos parece, una socarrona protesta contra los que se encumbran inmerecidamente, así sean los mismos hijos del pueblo:

$$
\begin{aligned}
& \text {...porque si llegase un bijo } \\
& \text { de un despensero a serlo [juez]; es evidencia } \\
& \text { que supuesto que es gato por berencia, } \\
& \text { aunque esté del león puesto en la cumbre } \\
& \text { vuelve, en viendo el ratón, a su costumbre. } \\
& \text { (La crueldad por el honor, III, iii). }
\end{aligned}
$$

Nos parece que la palabra "despensero" tiene aquí una significación moral, además de la de oficio, y que es evidente que el "gato", aunque esté por el favor del "león" puesto en la cumbre, es decir, "ennoblecido", no por ello deja de ser "gato" a la primera ocasión. Repárese además en que despensero (como sastre) es sinónimo de ladrón, no de hombre íntegro, y que al decir Juan Ruiz que el hijo del despensero es gato pór herencia, lo que está haciendo es un finísimo juego de palabras en el que sin rebuscamientos "gato" significa también ladrón.

Los méritos de este capítulo recapitulador superan a las objeciones que podrian hacérsele. Sin embargo, señalaremos dos pasajes con los que estamos en desacuerdo. Al referirse a lo externo, y más concretamente a los "cuadros de costumbres caballerescas", dice la señorita Brenes: "En este realismo externo, Alarcón complace al público; en el interno, en el que equivale a la verdad psicológica de los caracteres, no lo hace, puesto que el autor no se ajusta a los gustos del auditorio que exigía ciertas normas convencionales en la expresión de los carac- 
teres, sin interesarse por la realidad psicológica de éstos." (p. 223). Estamos en desacuerdo porque son precisamente las comedias del mexicano en que "la verdad psicológica de los caracteres" es lo más sobresaliente, las que más a menudo sc representaban, y sabemos que gustaban al público de aquella época que acudía a los corrales de la corte, así como a los de provincia, y tanto gustaban que se las imprimía y representaba como progenie de autores más "de moda". En el prólogo "Al lector", en el segundo tomo de sus comedias, Alarcón le hace saber a aquél "que las ocho Comedias de mi primera parte, y las doce desta segunda son todas mías, aunque algunas han sido plumas de otras cornejas, como son el Texedor de Segovia, la verdad sospechosa, examen de maridos, y otras que andan impressas por de otros dueños" ( $B A E, X X, p$. xlviii b), y que en el campo de batalla; que eso eran los corrales madrileños, salieron victoriosas de la prueba. Por ello le hace al lector la advertencia de que no se arroje fácil a condenarlas: "...advierte que han passado por los bancos de Flandes, que para las comedias lo son los del teatro de Madrid." (BAE, $X X$, xlviii, b). En cuanto al prólogo de la Parte Primera que ha podido dar la impresión de que no se aceptaba su teatro, téngase presente que aquí Alarcón se dirige "al vulgo", al que califica de "bestia fiera, que con la nobleza no es menester." ( $B A E, X X$, xlvii, b). Es decir, que su rencoroso deshago es contra aquella parte del público, sin duda los mosqueteros, que eran los más escandalosos, que no gustaba de sus comedias. Sin embargo, se puede apreciar que Alarcón consideraba que aquellos silbidos de la plebe habían otorgado a sus comedias algo así como un especial respeto que solamente se ganaba en aquellas lidias, "que ellas te miran con desprecio, y sin temor, como las que passaron ya el peligro de tus silvos" ( $B A E$, Loc. Cit.). No nos parece difícil hasta imaginar que en el corazón del indiano formaban parte importante de la "bestia fiera" aquellos famosos contemporáneos suyos que tan despiadadamente le zahirieron en su persona y en su obra: Góngora, Quevedo, Lope, Tirso, Montalbán, Vélez de Guevara, Solórzano, Mescua, es decir, lo más granado del público de los corrales y cuyas burlas no hacen sino probar los celos que sentían por la novedosa comedia alarconiana. Algunos de ellos hasta escribieron en colaboración con el mexicano. Pero, considerando sólo que a pesar del exiguo número de obras escritas por Alarcón, exiguo en comparación con la exuberante obra de Lope de Vega o de Tirso de Molina, aquél llegó a provocar violentos celos profesionales en el "Monstruo de la Naturaleza", y que la famosa contienda de El Anticristo nos deja entrever que el corral en que se representaba esta obra no estaba del todo vacío, tenemos que concluir que él también tenía su público. En fin, el nombre de Alarcón con los años dejó de ser famoso, peto no así la comedia más perfecta de su genio, pues cuando ésta fue a parar ante los ojos de Pierre Corneille ya llevaba como progenitor postizo a Lope, como garantía de que "era buena".

La otra objeción se refiere a un pasaje que nos parece contradictorio por el uso de ciertos términos, así como por la incoherencia del sentido: "Alarcón tenía que pintar con verosimilitud y realismo las costumbres y la vida caballeresca, porque sus personajes son los caballeros y damas convencionales de la comedia de capa y espada y el gusto del público exigía realismo." (p. 230). Lo uno no sigue a lo otro, y creemos que aquí hay cierta confusión. Esto, debemos señalar, 
es excepcional, pues en general se aprecia un clato discurso de las ideas, como en la página siguiente (p. 231) en que responde a su pregunta " $¿$ Moral de caballeros?", distinguiendo lo que ha de entenderse por "sentimiento caballeresco" en lo que concierne característicamente y sólo al entramado moral de la comedia alarconiana. (p. 231).

Apuntemos también como valioso el párrafo que cierra su conclusión: "En su comedia urbana de enseñanza moral, Alarcón utiliza un dualismo: lo democrático en lo interno, en su concepto de la moral y del valor del hombre, y, lo caballeresco, en lo externo, en las costumbres y convencionalismos de la vida aristocrática; en cuanto a lo espiritual, lo hondo de la vida, es democrático." (p. 234).

El libro de la señorita Brenes termina con una "Tercera Parte" que lleva como título "Conclusión" (pp. 235-259) y dividida a su vez en tres capítulos (X-XII). Esta Parte es un resumen de las dos primeras y repite una y otra vez lo que antes había asentado. En estos capítulos tenemos, en el $\mathrm{X}$ un resumen del contenido de los primeros tres (o Primera Parte); en el XI, una sinopsis de los cinco que forman la Segunda Parte, y como ésta, nos parece que es la aportación más valiosa, a pesar de las objeciones hechas y de otras que dejamos de hacer. El capítulo XII y último, que lleva como encabezado "Resumen" (pp. 252-9), nos parece francamente innecesatio y en extremo reiterativo. Además de que al hacerse aquí una sinopsis de lo que ya antes quedó resumido, el estilo de la autora sufre y lo que tenemos es algo que no queda muy lejos de emparentarse con un largo telegrama en el que se repiten encabezados, subdivisiones, incisos, conclusiones y las mismas ideas con idénticas palabras con las que el lector ha tropezado a menudo. La crítica de este capitulo la hacemos de buena fe y en parte nos asalta la posible disculpa de que tal vez se deba su existencia a la preocupación de algún director de tesis universitaria que deseaba leer algo concreto de obra tan voluminosa.

El libro termina con una bibliografía, un apéndice y la traducción de algunas citas del inglés, francés y portugués al castellano, que emplea la señorita Brenes en los primeros capítulos. De la bibliografía señalemos que a pesar de ser buena, abundan en ella obras generales que deben descartarse en un trabajo erudito. Asimismo aparecen en la lista varias obras importantes a las que precede un asterisco que indica que la investigadora las consultó pero no las citó, lo cual nos parece injusto, pues la labor de erudición habría mejorado. La bibliografía de artículos de revistas literarias es incompleta y para las omisiones que aquí aparecen remitimos al interesado lector a la bibliografía alarconiana que por estos meses publica mi colega Walter Poesse. Lo arriba señalado to hacemos de buena fe y sin menoscabo del trabajo que reseñamos, cuyos méritos no residen en el aparato erudito sino en una concienzuda labor personal. Anotemos que el error de citar el libro de A. Castro El pensamiento de Cervantes como si fuera un artículo de la RFE (p. 86, nota 5), aparece corregido en la bibliografía (p. 262).

Señalemos por último que el "Apéndice" (pp. 271-276) en el que la señorita Brenes hace un cuadro analítico de las cualidades de los criados en la obra alarconiana, resulta de sumo valor para el estudioso de la comedia. En este "Apéndice" se hallan los nombres de los criados y los títulos de la comedia en que aparecen, agrupados según el cuidadoso análisis que de sus cualidades morales e intelectuales ha hecho nuestira investigadora. 
En resumen, la obra de la señorita Carmen Olga Brenes es una importante aportación a los estudios alarconianos, y a pesar de ciertos desniveles y de repetir en parte lo ya observado por Henríquez Ureña, Reyes, Jiménez Rueda y Castro Leal, en los que principalmente se basa, logra con su perspicaz observación arrojar nuevas ideas para el entendimiento moderno del gran dramaturgo que sin ninguna duda se adelantó a su siglo.

Indiana University

Carlos Ortigoza

Carios Peliticer, Material poético, 1918/1961. México: Universidad Nacional Autónoma de México, 1962.

Tres poetas de la más reciente promoción -Rubén Bonifaz Nuño, Jesús Arellano y Raúl Leiva - han aunado sus capacidades de esmero y buen gusto para publicar la obra poética completa del actual decano de la poesía de México. Derroche de lujo, en papel de litografía y en tomo encuadernado de tamaño mayor a los de la Enciclopedia Británica, con artística cubierta de cartulina gris y un retrato en colores de Diego Rivera, pueden dar una idea aproximada del alarde editorial que significan las 662 páginas de estos 2,000 ejemplares del Material poético de Carlos Pellicer. Pocas veces un escritor que consagró su pluma nada más que a escribir poesías durante cuarenta y cinco años ha recibido en nuestro medio un homenaje más elocuente. El hecho merece destacarse muy especialmente, entre otras, por dos razones que consideramos de suma importancia: 1) que el poeta todavía goza en Hispanoamérica de esa venturosa consideración por la cual, como en los tiempos clásicos y renacentistas, se homologan las creaciones del arte a las más altas jerarquías del espíritu, en sitiales de honor y distinción; 2) que los valores poéticos de Carlos Pellicer, auténticos en su inspiración ya desde el primer libro, han mantenido su estirpe originaria en sucesivas etapas de renova. ción y afianzamiento, como un desafío a la afrenta del tiempo y a los cambios de gustos, modas, actitudes, contenidos y formas, inevitables en la evolución artística.

$\mathrm{Y}$ en verdad las once secciones que componen el volumen, correspondientes a otros tantos títulos de obras del autor, resultan un calcidoscopio en el que se muestran modos difetentes del hacer poético, que van del brillante colorido y la euforia impresionista — casi un escándalo de imágenes, alegría sensual y júbilo posesivo del mundo- a la ceñida meditación intima, la pregunta trascendente o la plegaria religiosa. Sensibilidad abierta a todas las dádivas del hombre, la naturaleza y los objetos de la cultura, Pellicer recoge la visión plástica del modernismo más sonoro y estetizante, para hacer de lo accidental y visible una suma esclarecida de sustancias y ritmos interiores por donde se desborda una voz henchida de glorias y de dichas que hacen vivir la tarde, el aire, el viento, el bosque, el mar, los ríos, el otoño, la aurora, el pájaro, la fuente, nubes y árboles, trópico, sol, viento, tempestad, el día o la noche, luz, oscuridad o niebla, con los goces 
de un alma que previamente se ha cargado de todos los ritos paganos y divinos. Sobre todo su primer libro - Colores en el mar y otros poemas, 1921, aunque empezó a publicar desde 1914- es, como el poeta dice del mar, no una presentación del aspecto físico del mundo, "sino una manera espiritual", pero a condición de que se hallen en el corazón los elementos principales" para subordinarse a él. En esa unidad armoniosa es natural que el canto se inicie con un

En medio de la dicha de mi vida

deténgome a decir que el mundo es bueno

por la divina sangre de la herida.

El poeta quiere sembrar la vida de "cordiales robles" y "ser bueno como el agua del camino", porque

Ser dichoso, Señor, no es ser divino

pero ser bueno, sí.

El sentido de lo humano se completa con lo divino en una entrega cordial sobre la cual Dios pone "la infinita corona del amor". Estos dos aspectos -el hombre creado en la naturaleza y el dado en lo divino o ansiando ser en la divinidadse mantienen como las constantes más hondamente sentidas y los tópicos decisivos de toda la poesía de Pellicer. Entre ambos polos, como fluida oscuridad o fría transparencia, surgen aislados reposos de juegos ideales, entonadas celebraciones patrióticas y americanistas (Bolívar, las Cataratas del Iguazú, los Andes, todo su segundo libro Piedra de sacrificios, "poema iberoamericano", 1924), travesuras infantiles, evocaciones de viajes, pintorescos brochazos de sorprendente imaginería, irónicos esguinces a la realidad, virtuosismos del Ultra e invenciones creacionistas, sin que falten las deshumanizaciones y el regodeo fastuoso de la pura metáfora "novi-estructural". Hoy el lector puede o no sentir el aleteo inocuo de versos como:

Mariposa, flor de aire, peina el área de la rosa.

O la esgrima intrascendente, aunque ingeniosa, de:

El buque ha chocado con la luna.

Nuestros equipajes, de pronto, se iluminaron.

Todos hablábamos en verso

y nos referíamos los hechos más ocultados.

Pero la luna se fue a pique

a pesar de nuestros esfuerzos románticos.

Estos versos -que son de Exágonos, 1941- revelan hasta qué punto llegó Pellicer en la faena de triturar esas "cuentas de cristal y de vidrio" en su aéreo 
pentagrama de "escalas rápidas y brillantes". Si eso mismo hubiese hecho en 1915, por ejemplo, su valor sería hoy muy diferente. Pero después de 1940, después de haber publicado aquel reconcentrado "Nocturno" que comienza con:
Alma,
has de llegar al gozo eterno,
has de volar con vuelo audaz.
La paz es fronda del invierno.
Tú en primavera tendrás paz...,

el rapto de la forma como ejercicio de maestría verbal, y nada más que eso, nos parece una vuelta a los tiempos del vértigo vanguardista.

En compensación, Pellicer tiene la otra vena, donde la altura de la perfección formal se mide con todas las honduras del pensar y del sentir. Pongo por caso el primer soneto de la serie de "Elegía nocturna" (p. 383), o aquel otro de la página 439 que empieza así:

Labró junio otra vez en carne viva

el campo del amor, y los terrones

su olor a entraña y húmedos talones

dieron al aire en que el amor cultiva.

En Práctica de vuelo (1956) y en algunos de los "Poemas no coleccionados" se da lo más denso del mundo poético de Pellicer, así como en sus primeros libros se había dado lo más brillante y admirable. A veces nos araña la piel con no bien pulidas uñas de retórica; otras deja de interesarnos, porque el poema es, como dice uno de sus versos, "pan sin levadura: ayuno de poesía" (p. 635). Sin embargo, queremos que se nos entienda bien: no estamos juzgando la poesía de este admirado poeta, sino tratando de situarla en su momento, en lo que fue y no ha dejado de ser. $Y$ en este sentido, Pellicer queda en la historia de la poesía mexicana como un hito señero, del cual, en cierto modo, arranca lo mejor de la poesía actual. Es, se puede decir, un "clásico moderno", con todos los atributos renovadores y permanentes de lo representativo. Viene después de González Martínez, por lo menos de aquel González Martínez que le tuerce el cuello al cisne y propone el símbolo del buho como vuelta a la interioridad del hombre y el mundo que se recobra en la percepción directa y la meditación del recogimiento. Sólo que en Pellicer el mundo exterior sigue existiendo sobre todo como una fiesta de los sentidos, como arrobamiento auroral, en el entusiasmo de las celebraciones dionisiacas, aunque sin lujuria pagana. Todo es en esta poesía de encantamiento y nobles virtudes una vuelta a lo elemental y primigenio, llena de asombros de niño inocente, "scherzos" de danzas y rondas recreativas, donde

Unas meditaciones llenas de cantos nuevos; encenderian mi frente.

El poeta no se cansa de elogiar: 


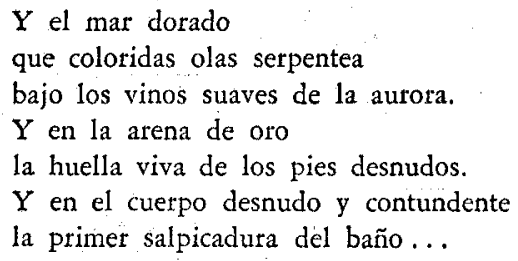

Hacia 1924, cuando ya triunfaba el Ultraísmo en América, Pellicer contribuyó -con 6, 7 poemas, 1924-no sólo a afirmar la metáfora y la imagen como la esencia virtual de la poesía, sino que abrió el camino para que los nuevos poetas de México otra vez instalaran en su predio nativo, en toda América, la confianza en las ofrendas de este Nuevo Mundo, las mismas que habian sido descubiertas pero no del todo aprovechadas por el lejano esplendor de Bernardo de Balbuena. Poemas como "La aurora" (p. 106), "Al dejar un alma" (p. 113), "Canto del amor perfecto" (p. 114), "Motivos" (p. 116), "Deseos" (p. 123), "Sembrador" (p. 134), "Segador" (p. 135), los paisajes de Hora y 20 (1927), son ejemplos de una inmarcesible nitidez poética. Con el soneto "Ruego" (1926) renueva otra altísima tradición en la poesía mexicana y española: la religiosa y mística, más cerca, sin duda, de Miguel de Guevara que de San Juan de la Cruz. En este aspecto nadie ha dado en México una nota tan real y vigorosa. Camino (1929) agrega la reflexión estética a la práctica creadora: qué es la poesía, cuál es la función de las palabras, las imágenes, los ritmos, etc., su verdadera acción sobre los elementos (el aire, el agua, el fuego, la tierra, y hasta la muette), donde el "cósmico templor" no le amedrenta la voz, sino que la desnuda y libera para

Sembrar en el campo aéreo, crecer alto a flor sutil.

Alguien podría advertirnos que esta poesía está exenta de una fuerte pasión amorosa. Y, efectivamente, el amor de Pellicer parece más pensado que sentido, más una aspiración indeterminada que una verdad acontecida:

Amor en cuya voz humildemente me refugié sin que el amor supiera.

Amor sin nombre, ámbito destino de ser y de no estar.

Los ocho sonetos de "Elegia" (pp. 238-242), tengan o no la viva llama del amor, son extraordinariamente bellos y penetran como un ave ciega en el encendido recinto de la ilusión, "la perfecta ilusión de su certeza", "al pie del alba en cuyo seno crecen/los espacios oscuros de mi vida". El poeta lleva el amor en su ser, pero en "un aquilino/palmo azul de silencio, vivo". Es muy probable que ese amor haya sido totalmente dado a la poesía. Así parece indicarlo el soneto titulado "Poesía": 
Poesia, verdad, poema mío,

fuerza de amor que halló tus manos, lejos,

en un vuelo de junios pulió espejos

y halló en la luz la palidez, el frío.

Pellicer es, en definitiva, una pura entidad artística, a pesar de ser tan humana su exaltación en la naturaleza, su acercamiento a Dios o su desolación más íntima. Como tal, no ve la realidad en términos de amor (en el sentido más original de pasión erótica), sino como un contemplador que sólo quiere nutrirse de belleza. Lo activo de esta actitud no es un fundirse física y espiritualmente con otros seres. Pellicer se queda afuera de toda realidad y actúa como un demiurgo, como un intermediario entre lo que lleva en sí y lo que recibe. Su función poética es la de un fogonero de sensaciones e impresiones. Funde, funde, pero no se quema. De ahí que el humo no le toque, ni el hollín; ni el fuego se apaga ni las cenizas lo cubren. "Poética del paisaje" o "Retórica del paisaje": la diferencia es poca. Invitaciones, reposos, esperas, arrestos; nocturnos, elegías, vuelo de voces, recintos de imágenes, un acariciar constante la piel que costea el país de los poemas; claridades siempre, luces reflejas, castillos de armonías o penas de horizontes que lucen como esculturas góticas, cubistas o figurativas; ansias, "manzana aérea de las soledades,/bocado silencioso de la ausencia", y, al final, el llamado a lo eterno, la pregunta que queda sin respuesta, en una hora de junio, que a la vez se pierde y atesora mientras el corazón "devora tiempos de oro". Lo que empezó siendo un canto a la luz auroral, un pedido de vida al cuerpo ardiente del trópico y a la grandeza cósmica del Andes, termina en una "elegía nocturna", donde cuerpo y belleza se unen para ordenar "este caos, esta nada/que el amor deja en mi":

\section{Nocbe en la altura \\ en que ya el corazón vive de nada.}

Se dirige a los signos perdurables de Nuestra América, se refugia en Dios, se adentra en sí mismo en "la hora de las palabras/terriblemente cristianas", para hallar la condición humana donde más la sangre vierte su ansia de ser humana; pero parece que sólo se encuentra en el frío fraterno de las estatuas, él, constructor de estatuas de la visión y de la mente, ruiseñor del canto azul y el aire claro, ángel de luz que no supo de tormentas, que estableció su morada en el relámpago y que si se acercó al mar con su cuetpo de efebo, sin las sombras terribles de la vida, sólo lo hizo para que apenas el agua le llegara a la cintura. En "Sonetos postreros" dice el poeta:

Vida de estatua, muerte inhabitada sin la jardinería de un anhelo.

Y proclama:

Mi voluntad de ser no tiene cielo.

Y luego:

Estoy lleno de nada y bajo el puente 
tan sólo el lodazal, la malviviente ruina del agua y de su platería.

Creo que el itineratio de Pellicer es bien claro, y aunque su conciencia más lúcida le obliga a confesar:

Yo, materia inflamable; codicioso de luz, muevo en la sombra el fruto que no he sabido dar...,

o

la belleza perfecta nada tiene que decir...,

alusión dramática a un quedarse fuera del reclamo de la hora en que vivimos, no podemos dejar de agradecerle el tiempo hermoso en que abrieron sus rosas aunque más no sea "la certeza de un día sin vida". Porque:

¿Qué mundo el de los ojos! Imprevisto

como la ordenación de lo creado.

......................

El Universo [aunque se lo ponga con mayúscula]

es sólo un ojo inmenso; su mirada

se ahonda en lo ordenado y lo disperso.

Desde la luz se mira hacia la nada.

Con razón Pellicer: puede concluir certeramente:

Palpé en mis manos frutos de destreza para reconocer mi poderío.

$Y$ al cuerpo desligado del Gran Río

la jícara del sol fue su cabeza.

En las luces quemadas de su estio vemos cómo la sombra de sus árboles empieza:

víctima de una aurora y de un ocaso

en el estar ya siendo lejanía.

Pero el poeta cumplió su misión, como un clamor de la naturaleza, olvidada en su tiempo, y en su voluntad mágica nos conforta el verlo cómo se detiene ante nosotros

$$
\text { sencillo, fraternal y planetario. }
$$


Alí Chumacero, Páramo de sueños seguido de Imágenes desterradas. México: Universidad Nacional Autónoma de México, 1960.

Se reúnen en este volumen los dos primeros libros poéticos de Alí Chumacero: Páramo de sueños, cuya primera edición (México: Imprenta Universitaria, 1944), mereció el premio otorgado por la revista Rueca a la mejor obra literaria del año, e Imágenes desterradas, publicado por primera vez, también en México, por la Editorial Stylo, en 1948. Ambas obras estaban agotadas; no así Palabras en reposo, que vio la luz pública en la colección "Letras mexicanas" del Fondo de Cultura Económica, en 1956. Evidentes razones de interés editorial han impedido que los tres poemarios aparecietan juntos y nos permitieran tener en un solo corpus toda la obra de este importante poeta. Lo lamentamos, porque cada nueva entrega ha sido una etapa diferente en la evolución poética de Chumacero, si bien dentro de una misma línea esencial, y no se puede hablar de las dos primeras publicaciones sin integratlas con la tercera, que es donde alcanza la cima de su trabajo de lucidez y pureza.

De intento hemos usado estos dos calificativos: lucidez y pureza, en los que la crítica ha venido insistiendo con unánime acuerdo. José Luis Martínez, por ejemplo, ha dicho que Chumacero es "dueño de una de las inteligencias literarias más claras y de una de las sensibilidades poéticas más puras entre nuestros poetas jóvenes" (Literatura mexicana siglo xx. Primera parte. México, 1949 , p. 190), y que "Posiblemente no exista entre los jóvenes ninguna poesía más estricta, consciente y lúcida que la de Ali Chumacero" (op. cit., p. 80). Y otro crítico de renombre internacional, Antonio Castro Leal, corrobora: "Su poesía, hecha con las más puras esencias líricas, es acaso la más alta expresión de las generaciones posteriores a Octavio Paz, Efraín Huerta y Neftalí Beltrán" (La poesia mexicana moderna. México: Fondo de Cultura Económica, 1953, p. 448). Juicios similares han emitido críticos más jóvenes y más urgidos, si se quiere, por exigencias de las últimas renovaciones poéticas, como Henrique González Casanova, Jesús Arellano y Raúl Leiva. Todo lo cual hace pensar en que el desiderátum del poeta ha consistido en la elaboración de ciertas alquimias indefinibles, en las cuales se hace radicar la "poesía más estricta" y las "más puras esencias líricas", entidades expresivas que, si tienen un valor en sí, por eso mismo no logran comunicar el contenido humano y los elementos diferenciales de una individualidad poética. Raúl Leiva titula uno de los más comprensivos estudios sobre Chumacero "En lucha con las palabras "(La Gaceta. Publicación del Fondo de Cultura Económica. Año III, Núm. 20, Abril de 1956, p. 2): perfección, rigor, inteligencia, vigilante entrega a la construcción, e inclusive, poesia hermética, en un plano de cierto aparente abstraccionismo, es lo primero que halla el crítico, si bien ve mucho más, $y$, a nuestro juicio lo que es superior g definitivo de Chumacero: ese algo "hondamente real" por donde "en estos poemas se da un testimonio de la agitada vida contemporánea, en una sociedad que le ha negado su sitio al poeta..." No se piense, por ello, que Chumacero sea un poeta de consigna, al servicio de tal o cual compromiso de partido, oscuramente dirigido con promesas mesiánicas o redentoras. No. La libertad del poeta nada tiene que ver con cierta literatura comprometida, simuladora de una 
salvación que apenas si cruza el río abyecto del más engañoso sometimiento espiritual. El verdadero poeta sabe-debe saber- cuál es el camino de la responsabilidad que no pone límite a la condición humana. Percibe, como un sismógrafo, la conmoción de su tiempo, la hace suya, y se lanza al futuro en una visión del mundo, en un sentido de la vida y en una actitud que es un modo de poseer y acarrear la existencia humana total, ya aniquilando estructuras que parecen inderribables, ya proponiendo otras que reclaman vigencias de un nuevo orden. Así entendida la misión del arte, resulta imposible admitir "la saludable creencia de la separación del poeta con la sociedad" (J. L. Martínez). El hecho de que los poemas de Chumacero "patentizan un labrado minucioso, un disciplinado sentimiento y un sentido penetrante de lo que un poema significa" ( $J$. L. Martínez), no supone, ni con mucho, que sea "poeta intemporal, despegado no sólo del mundo inmediato, de la circunstancia íntima, sino hasta donde ello sea posible y él lo ha hecho posible hasta límites extremos, del mundo mismo" (Henrique González Casanova, citado por Jesús Arellano en Poetas jóvenes de M!xico. Libro-Mex, 1955, p. 12); por el contrario, eso es lo que Jesús Arellano llama un poeta "sereno y seguro de sí mismo", que nos da "poemas llenos de augurios y propiedades trascendentes" ( $o p$. cit., p. 12), por más que "en sus últimos poemas se concentra demasiado dando a su voz un tono medio suspicaz [sic] y misterioso, tan escondido a veces, que hay que buscarlo con insistencia para poder gozar y entender bien lo que nos quiere decir su conciencia poética..." (ibid).

Falacia que prolonga ya demasiado el equívoco de la pretendida poesía pura es ésta de dar al arte una finalidad sin fin, de arte por el arte, de evasiones y sugerencias, de absolutos simbolismos impenetrables o de métier que a menudo conduce al artificio de una mera voluntad de forma. Todo verdadero poeta sabe que debe tener una forma, vehículo de sus vivencias, acaecidas o inventadas, de experiencias internas o externas, de sentimientos o de pensamiento, de simples imágenes del mundo visible o de intencionales significados trascendentes. En la poesía cabe todo esto, y por eso mismo, como dijo un gran crítico francés, no hay poetas fáciles, sino lectores fáciles. Si es tan difícil para un poeta hacer un poema, ¿por qué no lo ha de ser su inteligencia por parte del lector? ¿Son acaso fácilmente inteligibles las fórmulas químicas y los logaritmos matemáticos para quien no sea químico o matemático? ¿Tienen estas fórmulas $\mathrm{y}$ logaritmos más contenidos o menos convencionalismos formales que la poesía? He aquí preguntas que no pueden contestarse sino dentro del ámbito total de la cultura, fuera del reducto de la especialización, las minucias del oficio, la indolencia del hedonismo, la fácil salida de la concepción lúdica del arte. Forma, hermetismo; perfección, puteza; técnica y creación, son ingenuos comodines con que la crítica parece engañarse a sí misma. Crean la ilusión de que se está diciendo lo que ha hecho el poeta, pero poco nos aclaran el sentido de su poesía. O sea: cómo la ha producido, por qué y para qué. Porque la poesía no es producto de Dios ni de la naturaleza; la hace el hombre, un hombre concreto, de carne y hueso, con su cuerpo y su alma, sus vicios y virtudes, la materia revuelta en el fango de la vida y sus apetencias más limpias de aspiraciones ideales. Como transferencia simbólica -está bien que el poeta sea un ruiseñor, 
un cisne inútil, Narciso, una estrella o el buho de la noche enigmática. En la realidad el poeta es un hombre como cualquiera, que trabaja en una oficina, se emborracha en una taberna, se convierte en maestro desde la cátedra, se debate con la prensa mercantilizada, fornica en el prostíbulo o ama y procrea, como Dios manda, fiel a la esposa y el hogar y ejemplo de sacrificio y de trabajo para su prole y la sociedad. ¿No es esto verdad, señor Chumacero, amante esposo y modelo de padre y hasta de empresarios editoriales? Pues bien: ¿para qué disimulat entonces? Hablemos claro y seremos francos y leales con nosotros mismos y con los demás. Que otros cuenten adjetivos y medidas, metáforas, sinécdoques y metonimias. La retórica ya no se escribe con mayúscula y la estilística está bien para ciertas tesis universitarias. Ahora tenemos otros problemas, que son de vida o muerte: hay que roer el hueso, chupar la medula, sorber sangre pura o contaminada, tragar el aire infecto, ver como nos destruye la civilización, sufrir la amenaza de nuestra muerte diaria, debajo del mar o más allá del cielo, no sentir cómo late nuestro corazón ni saber si vale la pena tener una idea o el más elemental derecho de vivir. Páramo de sueños es el hombte; bien lo sabes, gran poeta, $y$ esto no es un juego de palabras. Más aún: si tuviéramos la pedantería de medir tus versos con el cartabón de la gramática, la fonética u otras invenciones profesorales, es posible que poco quedara invulnerable de "Muerte del hombre", como no sea la tremenda verdad que lo sostiene. Y esa rosa que cae, "atravesando el agua", de "Una flor inmensa", que parece la visión de una pesadilla noctámbula, ¿que valor de pura forma tendría, si no fuera por su significado íntimo, profundo, que la convierte en símbolo del canto del poeta, de la misma belleza, viva y actuante "en la mirada de un canario herido /que atreve el último aletazo/ para internarse mudo entre las sombras". "Vencidos": sí, vencidos están los "caídos descuidados al abismo"; pero el poeta no, porque si "nada delata que existimos /en esta soledad del pensamiento, / y el olvido desciende hacia la tierra / como un equívoco de Dios...", "lo que alimenta nuestro amor" es "el implacable continuar entre los hombres". Estamos "frente a la muerte", sí, "como sombra apresada en las tinieblas /que quisiera hallar una luz / para poder nacer", pero no queremos, no debemos "morirnos en nuestras propias manos..." En "Anunciación" puedes exclamar: "Esta es mi sangre", y en "Realidad y sueño" te recuestas en tus venas "con la blancura intima del niño aún no nacido". Luego viene "En la orilla del silencio", donde quisieras decir: "Aún existo", y comienzas "a descubrir cómo el misterio es uno /nadando mutilado/ en el supremo aliento de mi sangre", y sientes "que ya el sueño navega en el misterio". "Jardín de cenizas", "Debate del cuerpo", "Amor entre ruinas", "Amorosa raíz", "Desvelado amor", "La forma del vacío", y entre "Espejo y agua", la sucia y humana carne que mueve los sentidos -el sol y todas las estrellas-, el agua que limpia y nutre hasta que "El sueño de Adán" haga sentir "el corazón como un aroma", y la voz se torne en pensamiento, y en palabras que crean esa realidad "Nacida nuevamente de mi sueño". El Páramo de sueños ya no es un cementerio de muertos -aquel "cementerio marino" del poeta que creía en el "suceso puro"-; no, ahora es un paraíso de almas, con Evas y manzanas, con serpientes y pecados, porque hay un hombre que lo habita, veneno o miel, no importa, pero si humanidad que anda. Por 
eso puedes, después de cuatro años de existencia verdadera, dejar el "Tiempo desolado" y verte en sus Imágenes desterradas. Ahora ya no eres un Narcișo vegetal, la flor inútil, sino un "Narciso herido", que escucha "el duro palpitar", el "desplome del tiempo", y a él -a ti mismo-, puedes decirle: "Se alzan mis ojos contra tí", "en mí tu pensamiento se maldice, /tu pureza se vierte conmovida a la violenta maldición que anega /sin otra salvación que mi pecado". ¿Poesía pura? No. "Pureza en el tiempo": "No habrá milagro o salvación posible"... "Porque nadie /buscando la pureza ha sonreído". Este itinerario podría ser más explícitamente expuesto, sin duda; pero lo que hemos querido es demostrar que esta poesía no es una esgrima de palabras, un simulacro de la forma, sino una búsqueda del hombre (del vital y del estético), su conocimiento (diría poesía gnoseológica si la palabrota no fuera tan pesada para las frágiles alas de la poesía), una teoría del ser, pero sin doctrina de sistema mental; ontología, pero nacida de la urgencia vital, no de la dialéctica de la razón que deja intacto el río de la vida. El hombre concreto, en la futia de sus sentidos, la pesadumbre del cuerpo, el instinto devorador, la oscura potencia del mal que se levanta como un muro infranqueable entre la vida y la muerte, entre lo que tira de abajo hacia el no ser y la verdad del deber ser, nuestro destino último. Lucha agónica que se fortalece en el único posible asidero humano: el amor. En el "Poema donde el amor dice" parece hallarse la clave de esa lucha aún incierta:

Eres el tallo que los ojos hiere

murmurando una luz anochecida;

eres aliento encadenado al fuego,

paloma navegando en la mirada

con la inocencia de disuelto aroma.

Eres tal un murmullo transparente

en temblorosa vibración vertido;

eres flor de aire que navega incierta

como sonoro viaje hacia el oído

o aleteo herido de azucena.

La referencia a una experiencia concreta del hombre - humano, demasiado humano-, no impiden la posibilidad del salto a otras supuestos que den razón de la vida cotidiana en un más allá, aunque sólo sea esa "ceniza de tinieblas y de abismo"... "y la tristeza última del sueño" con que se cumple la "Destrucción de los sentidos". Queda como único apoyo de una realidad entrevista esa "lánguida ceniza /o la eterna viajera fugitiva", para poder decir: "Imagen mía,/ perdida por los siglos de los siglos", de la "Elegía de la imagen". ¿De qué imagen? ¿De la amada concreta, ya perdida? ¿Del amor como fuerza de una realidad que se persigue? ¿De la belleza misma aún no lograda? No pidamos tan clara definición a los poetas; la realidad de la poesía, como la de la vida, se hace con preguntas, y nunca con respuestas. Para éstas están la ciencia 
y la filosofía. En el poema "El secreto" el poeta desea que ese secreto permanezca "entre el salobre aire de misterio":

Pregunto al rostro que tinieblas vence,
adivinando si en la superficie
muere un viaje iniciado desde el alma...
y los labios callados permanecen
ignorantes guardianes de un secreto.

"Al aire de su vuelo", "Ojos que te vieron", "Inolvidable", "Elegía del recuerdo" son sentidos poemas de un amor experimentado en el concreto suceder de cualquier criatura de este mundo, pero con la diferencia de que el poeta se crea en el objeto amado, "dentro del alma", y "el corazón halla reposo en ti, pues nuestra noche /es infinita y pura en su delicia". Así se logra "La transfiguración", con un turbio renacer del "lánguido delfín del pensamiento", impuro todavía en los sentidos. El poeta habla de su "duelo", de "la tempestad sin fin de los olvidos", de "Palabras que nacen del vacio"; "sobre el misterio de la tierra", en una soledad que no ha vencido, el corazón "se incendia a solas cuando advierte /que allá donde simula paraíso es ella la evadida"... y en mi alma refleja/ la desesperación de quien en torno mira/ un horizonte fatigado/ por espesas tormentas de ternura". Otra vez la pregunta: jes la amada concreta, la mujer, o es otra cosa: la realidad vital, la belleza, la perfección, la pureza? El último poema parece darnos la respuesta, evasiva y simbólica, del "Laurel caído":

Y soy la soledad del náufrago jazmín que en el viento prolonga su propia destrucción, conciencia amarga o duelo por quien herido yace sobre su arena inútil muerta sobre sí misma.

Iba quedando solo, huérfano de unos ojos donde yo me veía equilibrado círculo, para siempre hoy perdido Ulises de mi cuerpo, mareado viajero que a las olas se olvida mirando entre su sombra la sal de su desdicha.

Contigo descubria nuevamente la tierra $y$ el agrio aire suyo y las flores dormidas; supe de aromas fúnebres, de almas desoladas y de pronto en mi rostro la muerte se movía.

Yo dije una palabra y en ella navegaste: era tu nombre escaso, la breve transparencia 
tornada resplandor bajo mi pensamiento; después miré a tus ojos y los miraba áridos, ribera del reposo donde tranquila oleaba la armonía del tiempo, inconteniblemente.

Mas de nuevo las rosas languidecieron, pronto dejaron el urdido afán que las anima, cuando lento en tus labios íbase desmayando el "adiós" que me habría de recobrar un mundo; mi playa, la perdida, la solitaria arena habitada de lágrimas, y el asolado sueño donde tu ausencia crea la forma de la nada.

¿Hay aquí simbolismo o no? La dificultad de entender a un poeta consiste en que él expresa lo trascendente y universal con el minuto más terco e indescifrable de su individualidad. Lo que queda es la atmósfera que nos envuelve, donde las resonancias intimas se convierten en ecos de una situación compartida, que es de todos en el tiempo en que se vive. Chumacero no es un poeta aislado, sino la culminación de un proceso en el que el individualismo moderno, desde el "Pienso, luego soy", hasta el "Yo absoluto" y la disolución de lo Uno y diferente halla su contrapartida en el Otro. Si lo personal e individual no logra su integración con el mundo y la multiplicidad vital de su tiempo, sobreviene el ensimismamiento, el rechazo aniquilador, la angustia, la desesperación, la nada. ¿Existencialismo? ¿Conflicto entre la esencia y la existencia? Puede ser. Chumacero, hombre y poeta, no ha encontrado su "habitat" en el mundo en que le toca vivir: éste es un "Páramo de sueños", y su esfuerzo por hallar una salida salvadora apenas puede mentar los signos de sus "imágenes desterradas". Por lo menos, eso parece suceder en estos dos libros tan dolorosos y hasta crueles para la legítima razón de ser de la condición humana. Será preciso que transcurran otros ocho años para que el pesimismo y la desdicha encuentren alguna esperanza y la calma de sus Palabras en reposo. Se repiten los temas fundamentales ("El orbe de la danza", por ejemplo, es un complemento de "A una flor inmersa"), las mismas fuentes inspiradoras (el amor, la soledad, el "duelo", el destierro, ahora "apacible", sin tempestades, y entre otros motivos circunstanciales, nada separados del mundo y de la vida cotidiana, el destino del hombre, la eternidad del ser); sólo que ahora "Alza la noche el salmo del olvido, $/[\ldots]$ y al sonoro desfile del corazón suspende/ el fragoroso dueIo". Y "todo en silencio a la quietud navega". El pecador que a orillas de unos ojos mira nacer la tempestad (en "Responso del peregrino", su poema más ambicioso y fundamental del libro), ahora recoge un "sumiso dardo, voz en la espesura" e incrédulo desciende "al manantial de gracia". "Relámpago vencido /en la límpida zona de laúdes", una paloma se insinúa en "páramos amorosos y esperanzas", "erigiendo en olas/ el muro de mi salvación". Ella (la amada, la poesía, la belleza, la realidad hallada, lo que sea) ahora aparece "purísima y transida, arca, paloma, lápida y laurel", y en una "Fiesta de Pascua, en el desierto inmenso", sólo le es dable añorar la tempestad. El gran poema "Mar 
a la vista" es un complemento de "Ola", del primer libro. En "Ola", lo vital era lo "oscuro /como paloma que de pronto niega/ de su mármol idéntico el estío" (recuérdese el mismo vocabulario, los mismos símbolos, las mismas soluciones de "El cementerio marino" de Paul Valery). En "Mar a la vista", el poeta, "ciego de ver en la aridez del alma / la omisión, el insomnio, la funesta/ amargura, sostén de la derrota", mira hacia el mar "y el agua es forma pétreal de impureza mortal", porque enseguida viene:

Vano ceñir la túnica engañosa, emblema del cordero entre laureles, su gracia hiere los espacios, etc.

Ahora el poeta introduce "el frío símbolo / del tigre a quien invaden los crepúsculos", por el cual, "sano y salvo" parece horadar las murallas del temor e iniciar así, como Lázaro, el camino de la resurrección:

Húmeda melodía, al labio fluye armoniosa de llamas la palabra: ita en el templo o dardo moribundo, Lázaro yergue el rostro, toca el paño y a sus ojos despliégase el vacío.

El bien y el mal, la vida y la muerte, el alma y el cuerpo, la esperanza y la desesperación, el ser y el no-ser, por último, se resuelven en las correspondencias bíblicas de Marta y María, en quienes es posible también hallar las equivalencias para lo individual y lo social, el ensimismamiento y el prójimo:

\author{
Marta, María y el horror circundan \\ la aureola de Dios y su mirada; \\ sobre mi oído "Lázaro, ven fuera" \\ persiste aún $y$ a la solemne arcilla \\ me atrevo a interrogar: "¿Quién es mi prójimo?"
}

Parece que el poeta, el hombre, persiste en su intransferible individualidad, como un cadáver condenado a muerte, precisamente porque se aferra a la invariabilidad:

\author{
En medio de la arena, frente a un mundo \\ sin más consolación ni movedizos \\ resplandores, mi mano determina \\ la invariabilidad, el in llorando \\ sobre un cadáver condenado a muerte.
}

Otros poemas pueden completar este discurrir de la poética de Chumacero. Nuestro propósito ha sido perseguir su sentido más entrañable y trascendente. No 
estamos seguros de haberlo logrado. El poeta es un pez que se escurre entre las ondas oscuras de un mar encabritado. Es esa "unánime y azul sublevación del mar", que dijo otro gran poeta actual, el ecuatoriano Jorge Carrera Andrade. Sea o no eso que decimos de la poesía de Chumacero, quede como excusa el deseo de ir a buscar la poética donde creemos que debe hallarse: adentro $y$ en el fondo oculto del poema. Deliberadamente hemos excluido el análisis de los medios expresivos, procedimientos y otros elementos formales, cuya importancia no deconozco, por supuesto, a fin de evitar que lo externo y visible interfiriera lo interno e invisible. Decía Ortega y Gasset que las palabras ocultan el pensamiento; nosotros creemos que también encubren la poesía.

Nada es claro de por sí. La misma naturaleza es un misterio, y Dios es más oscuro que los hombres, porque nunca se deja ver. La claridad o la oscuridad de la poesía depende de nosotros. El poeta, si lo es, nunca es oscuro. A lo sumo será difícil de entender, $y$ esto también depende de nuestra capacidad para llegar a él. Por lo demás, el lector tiene el derecho a aceptarlo o rechazarlo, según sus intereses, gustos y posibilidades. También reservamos al lector el derecho de clarificar u oscurecer la obra poética, pues esto es tan inocente e inofensivo como la poesía misma. Con perdón, pues, si hemos errado. "El alma del poeta se oriente hacia el misterio" (Machado) y el lector se conforma a veces tan sólo con sentir ese "peso confuso" sobre su cotazón.

State University of Iowa

Alfredo A. Roggiano

María dei, Carmen Mrllán, Literatura mexicana. México: Editorial Esfinge, S. A., 1962.

En los círculos universitarios de México, Hispanoamérica y Estados Unidos, María del Carmen Millán es una profesora estimada por su simpatía, su fino espíritu y su generosidad concorde con la tradicional hospitalidad mexicana; en el ámbito académico de los altos estudios y la investigación literaria, es unánimemente respetada por su segura información, su sensibilidad, su capacidad docente y su responsabilidad crítica. Desde 1954 es profesora de tiempo completo de Iniciación a las investigaciones literarias y de Literatura mexicana en la Facultad de Filosofía y Letras de la Universidad Nacional Autónoma de México, donde tiene a su cargo, además, el Seminario de Literatura Mexicana y la Dirección del Centro de Estudios Literarios. Asimismo es Consejera técnica del Departamento de Letras y ha ejercido las funciones de Secretaria de la Facultad de Filosofía y Letras. Ha publicado una selección de Cuentos mexicanos (México, 1946), El paisaje en la poesía mexicana (Imprenta Universitaria, 1952), Ideas de la Reforma en las letras patrias (M!xico, 1956), un volumen dedicado a la Poesía romántica mexicana, con prólogo y selección propios (México: Libro-Mex Editores, 1957), cuidadas y eruditas ediciones en la "Colección de Escritores Mexicanos" de la Editorial Porrúa, y artículos, estudios y notas en revistas espe- 
cializadas de México y Estados Unidos de Norteamérica. Estos antecedentes bastarían para asegurar que era la persona indicada para escribir un manual de la literatura mexicana ajustado a los programas oficiales del bachillerato. Pero la obra que ahora nos ocupa no ha surgido sólo de su experiencia en la enseñanza impartida en escuelas secundarias y preparatorias de su país, sino que es el fruto de una elaboración minuciosa realizada como parte de su carrera del doctorado en letras, título que acaba de obtener en la mencionada Universidad.

Durante años María del Carmen Millán ha venido ahondando en los diversos períodos de la literatura mexicana, ha perfeccionado sus conocimientos conforme a las mejores técnicas de investigación, al lado de maestros de prestigio internacional, y los ha ordenado con riguroso método y conciencia pedagógica dentro del cuadro general de la cultura de México y de la América hispánica. Así, el lector que recorre las 349 páginas de este denso, claro y preciso compendio de Literatura mexicana, complementado con notas de literatura hispanoamericana, una antología bien seleccionada y una bibliografía mínima fundamental, no anda de la mano de un árido especialista que minimiza los hechos literarios en meras clasificaciones, el dato elemental, la anécdota baladí, el convencionalismo formalista o la reducción a un estrecho nacionalismo. En la "Advertencia", con modestia pero con seguro dominio de la materia que maneja, dice la autora: "Se trata de un trabajo de síntesis que, como todos los de su clase, tiene forzosamente algunas omisiones. Sin embargo de ello, se ha buscado, siguiendo el orden lógico de la cronología, presentar los panoramas generales de cada época y destacar las figuras de primera importancia en cada una, dentro del género literario a que corresponden. Por lo que se refiere a la literatura hispanoamericana, se ha considerado conveniente incluir, al final de los captulos, breves notas que sitúan a los autores representativos, con el fin de establecer las relaciones entre las diferentes literaturas hispanoamericanas y la mexicana, sin que se pierda por ello la secuencia histórica en el desarrollo del asunto que primordialmente se expone".

El objetivo está ampliamente logrado: en trece capítulos los estudiantes y estudiosos de nuestras letras tienen a su disposición, sin huecos lamentables, sin desperdicios y sin adyacencias inútiles, ajustados y sapientes cuadros de las literaturas prehispánicas, los siglos de la Colonia, el período independiente, el Modernismo y la época contemporánea. El orden cronológico se integra con el estético, en la clásica división de poesía lírica, épica y dramática; en la prosa de las crónicas, la historia documental, la oratoria política, las diversas manifestaciones religiosas y culturales (gramática, ciencias sociales y arqueológicas o técnicas, etc.), el cuadro de costumbres, la novela, el cuento, apólogos, fábulas, ensayo y cuanto género $o$ especie han tentado la pluma de los novohispanos. $Y$ todo visto en su raíz, de primera mano o apoyándose en la bibliografía crítica más autorizada, con un sentido exacto de lo americano y de las contribuciones foráneas, dicho con sencillez y esa economía de medios de quien posee lo esencial y lo ha logrado con luces propias. Porque la doctora Millán es persona de principios y convicciones que arraigan en el prestigio de una alta cultura heredada y se afirman en el proceso inaplazable de la evolución cultural y artística. Con una formación tan bien lograda y con cualidades innatas tan excelentes, María 
del Carmen Millán, tan callada y ajena al relumbrón del éxito, nos ha dado una obra seria y útil, en un plano que integra, con singular maestría, la difusión fácil, adecuada y necesaria, con las exigencias de indeclinables jerarquias del saber.

Nos referimos, claro está, a lo que un trabajo de esta índole tiene de riesgoso cuando deben estimarse los valores estéticos dentro de las estructuras conpelidas por lo histórico y lo cultural representativo. Quien ha debido ceder gran parte de sus convicciones y gustos en favor de una objetividad que pueda adecuarse al interés general, queda sobreentendido que no podía librarse del rito de los sacrificios en el altar de los ídolos nacionales. Y es lógico que cada sacerdote pida más incienso para su capilla. Un uruguayo dirá, por ejemplo, que Zorrilla de San Martín es, literariamente, más valioso que el argentino Bartolomé Mitre, aunque posiblemente no tenga la misma importancia histórico-cultural. Un historiador del teatro hipanoamericano no justificará la ausencia de Samuel Eichelbaum y Conrado Nalé Roxlo; el estudioso de la poesía objetará que Rubén Dario, Leopoldo Lugones y otros están deficientemente representados; el especialista en novela, cuento y ensayo dirá que faltan Alejo Carpentier, Jorge Luis Borges, Miguel Angel Asturias, Mariano Picón Salas o Francisco Romero. Y en una visión totalizadora, se hacen visibles ausencias de figuras tepresentativas de varios países de Hispanoamérica - sin contar el Brasil, que ha sido totalmente excluido- en los varios períodos de las respectivas historias literarias. Pero lo que dará más motiva a opiniones divergentes es la parte dedicada a la época contemporánea, donde el criterio de selección no puede apoyarse en la autoridad definitiva del tiempo. Por razones obvias, los capítulos. XII y XIII serán los más susceptibles de críticas y los más necesitados de revisión en futuras ediciones. Esto, no obstante, en nada amengua el mérito indiscutible de la inteligente labor de la doctora Millán, mexicana que honra a la cátedra de México y se eleva como modelo de dignidad intelectual para la mujer de América.

State University of lowa ALFRED A. ROGGIANO

Arturo Torres Rioseco, Autobiografia. Madrid-Palma de Mallorca [De "Papeles de Son Armadans", Núm. LXX, Enero de 1962], 1962.

Es éste, si no contamos mal, el onceno libro poético de Arturo Torres-Rioseco. Desde En el encantamiento (1921), versos de juventud (tenía 24 años de edad) con los que se inicia en la vida literaria, auspiciado en Costa Rica por una edición de García-Monge y un prólogo de R. Brenes-Mesén, hasta la fecha, suman cuarenta y dos años de trato con las musas. Sin embargo, el destino del poeta ha quedado un tanto relegado cuando se lo compara con la reputación ad. quirida por el investigador, bibliógrafo, antologista, ensayista, historiador y crítico de la literatura hispanoamericana. Este aspecto de su personalidad, que se ha venido desarrollando como parte de su labor docente en cátedras universitarias, círulos académicos de alta cultura, viajes de conferencias, congresos, revis- 
tas especializadas, etc, ha pasado a ptimer plano; y hoy el prestigioso profesor chileno sufre una especie de "suerte hibrida" — son sus palabras-, indeseada y lamentada por quienes se sienten primordialmente creadores. Cierto que no han faltado voces autorizadas, como las de Federico de Onis o Gabriela Mistral por ejemplo, quienes oportunamente supieron destacar los valores del poeta; pero todavía hay historiadores y antologistas hipanoamericanos que se niegan a concederle un puesto en nuestra república literaria, como no sea el de pioneer de la cultura de la América Hispánica en Norteamérica. Precio agrio es éste que a menudo debe pagar el maestro generoso, consagrado más a enseñar obras ajenas que a mostrar las propias. O bien saldo ingrato, se me dirá, recogido por quienes, voluntaria $o$ inconscientemente, se excluyen de participar en las demandas del éxito, el péndulo de las modas, el ritmo inevitable de la evolución artística. Todo es bueno y nada también, me respondió cierto día un campesino español al preguntarle yo por qué cortaba, con el trigo que había sembrado, las flores que la naturaleza había hecho crecer, como un prodigio, sobre el campo que segaba. Paradojas del sembrador, sin duda, para quien lo útil y necesario no siempre se computa con lo verdadero. O razón del artista, quien asume su verdad cediéndole a la nada el paso de lo útil y lo bueno. Porque la belleza es esa nada del misterio donde el poeta cosecha las flores del milagro. $Y$ la poesía es el único trigo de la vida que produce el pan eterno.

Veamos ahora si el laborioso sembrador de Talca, entre tanta cosecha útil, de la que muchos nos aprovechamos, ha dado también, para sí y para los demás, en ese secreto recinto del alma no violado por las fatigas del mundo, el grano eterno de la poesía. Partiré de una confesión de Ausencia (1932), su segundo libro de pocmas:
No quiero ver mi destierro, ausencia que te haces grata, pluma sobre mi sendero, bajo mi nariz fragancia; deslumbramiento en los ojos, en mis orejas campana, hormigas que se alimentan de la inquietud de mis plantas.

He aqui expresada una situación vital que deja entrar la poesía por las puertas de lo humano, antes que por el arte bien aprendido. Quien se ha pasado la vida examinando técricas y doctrinas para penetrar en el difícil mundo de miles de poetas, no ha podido escapar a la contaminación de la forma; pero tampoco podia ésta dominar del todo una realidad esencialmente personal. En los "contenidos" de esa realidad y en el sentido integrador de sus "formas" expresivas habrá que buscar, pues, lo distintivo y propio de la poesía de Torres-Rioseco. En un examen de sus diversos libros, lo primero que se advierte es el avance de un proceso, paulatino y consciente, que va de la asimilación a la creación; claro esfuerzo por liberarse de lo dado, y "hacerse", ser en lo nuevo, aunque 
sin desdeñar lo que del pasado ejerce comando de permanencia y enriquecimiento. Federico de Onís, al incluirlo en su conocida Antología... (p. 1002), dice:

En su primer libro de poesías es claramente un postmodernista y en el último' [se refiere a Ausencia] no acaba de ser un ultramodernista. Su poesía es moderna y conservadora: hay en ella una contradicción interna. Oscila entre la sencillez y el retorcimiento, el clasicismo y el romanticismo, la exaltación vital y un crudo e irónico pesimismo. Es una poesía de ideas y pasión, con timbre personal.

En vista de $\tan$ encontrados elementos, Onis no pudo encasillarlo en una tendencia definida, y resolvió situarlo en la transición del modernismo al ultraísmo. ¿Quiere decir esto que en sus dos primeros libros Torres-Rioseco andaba a la zaga de la poesía de su tiempo? Recuérdese que en 1932 ya habían publicado parte de su obra todos los grandes de la nueva poesía hispánica: J. R. Jiménez, Huidobro, García Lorca, Pedro Salinas, César Vallejo, J. L. Borges, G. Mistral, J. Carrera Andrade, C. Pellicer, Rafael Alberti, J. Guillén, A. Storni, Pablo Neruda, etc. El "creacionismo" de Huidobro y el "ultraísmo" que Borges difundió en Buenos Aires estaban ya consagrados y hasta suplantados. En Ausencia nada encontramos de "ultras" y "creacionistas". Por el contrario, todavía "se defienden" alli algunos resabios de modernismo tardío. En un poema titulado "La mujer mejicana", vemos una "pupila de brasa", una "lengua de campana", unas lugonianas "elasticidades ardientes de gatas", etc., junto a vivencias más personales y de franco sabor clá. sico y acento criollio:

Mujer mejicana:

tu parla parece tejido de lana.

Hay en tu ademán

la tibieza lenta del vaho

que sale del horno donde se hace el pan.

Todavia en Mar sin tiempo (1935) Gabriela Mistral ve "una vajilla que contiene piezas modernistas, aunque la mayoría sean alfarería criolla".

Por venturosas rendijas de la "alfarería criolla" se escaparon los modernistas hacia diversos rumbos: vuelta a lo clásico, a lo romántico, a la tradición española de los romanceros y los siglos de oro, a lo americano, criollista y nacionalista, a la poesía social o a la pura evasión de la imagen. Para Torres-Rioseco fue, ante todo, una vuelta a lo hispánico del romancero y del siglo de oro: un Canto a España viva (1941), libro que se mueve entre la desesperación libertaria de la guerra civil y el zumo rejuvenecedor de García Lorca. Fue asimismo el encuentro del hombre con su mundo, en la nutricia compañia de seres afines, ideales comunes y sentimientos compartidos. Exaltación humana que comulga con las cosas y se enfrenta a problemas fundamentales de la existencia; pero también descubrimiento de la soledad, deidad a la vez de paz y de guerra, como Jano, cuyos rostros concertatán el dolor con la dicha, la angustia con el sosiego, el pesimismo 
con la esperanza, la fluencia lírica del sentimiento más confesional con la meditación severa de remontado tono metafísico. Elegias (1947), Cautiverio (1955), Madurez de la muerte (1959) y Autobiografia (1962) son escalas de ese viaje inintertumpido en el que el poeta va llenando sus maletas con experiencias de afuera y de adentro para su meta definitiva.

Cautiverio es, como reza el subtítulo, una "antología poética" que recoge la producción de tres lustros, de 1940 a 1955. Se abre con una sección de dieciocho sonetos, de ajustada estructura hispano-renacentista, con dejos de barroquismo y conceptismo, cuyo tema central es el amor en soledad dichosa o un "morir sin morir" que implica un llamado a la muerte o a la creación salvadora. Siguen otros sonetos dedicados a Entique González Martínez, Mariano Azuela, Pedro Prado y Gabriela Mistral, saludos en romances a Alberto Rembao y Ernesto Montenegro y composiciones de variado contenido, estrofas, metros, etc. Desde el "estilo-conversación" del "Saludo a Ernesto Montenegro", el "Canto a Guatemala" y "Canto del Quetzal", hasta los "Denuestos a la muerte" y la "Elegía sencilla", se convive con formas clásicas y modernas, realidades directas y mundos de apariencias, hechos pasados y presencias puras, en elaboraciones que dejan ver el esfuerzo adquisitivo rondando el fuego de una auténtica inspiración. Destaco "Las llaves" como pieza de antología, donde hay que detenerse en creaciones tan avanzadas como "el nudo de tu miedo", "tu claridad de gaviota encendida", "el candado azul de tus designios", "el anillo puro de la naranja", "hoja de perejil tejida en alba", "el túnel negro de la arena", y muchas más; "Puro diamante", por el cuidadoso y lucido ensamble de lo subjetivo en lo objetivo; "Oh, tú debajo de la muerte", por el estremecimiento humano comunicado a las cosas que rodean el vivir diario: lo trascendental puesto a los pies del dolor físico, y la "Elegía sencilla", que es, podríamos decir, un ejemplo average de la poesía que mejor puede caracterizar la personalidad y el estilo de Torres-Rioseco:

Ahora la estrella escucha

tu voz de hoja, muerta, tu voz sin eco, rota en un gerundio.

¡Oh! nota helada, sal, de nota, en un viento de vidrio sin ternura.

Por ese tubo soplan

plegarias, alaridos, campanas, se cuelan -duro verbo fríopalabras sin sonido, estériles palabras de la muerte.

Ahora sólo la estrella reconoce la voz y la desnuda.

Frío azul en la altura de la nieve; rocío congelado.

En esa hora el polvo, el ala del murciélago, el ímpetu quebrado, Ia ceniza que te cubrió la piel. 
En tu morir de noche, de espesa sangre torpe, de piedra indiferente, con. una voz $\tan$ suave, recogida en la estrella. Voz de hoja muerta en la estrella, por siempre.

(pp. 177-178)

En Madurez de la muerte (1959) el "río de la vida" avanza, sin goznes de retórica, menos atado a la preocupación del pasado, en cantos celebrativos de muertos ilustres, estremecido ante "la espera constante/de la sombra", entre "lo no revelado y presentido" ( $\mathrm{p}, 17$ ). "Muerte mecanizada" es uno de sus poemas más fuertes y originales, donde el pavor del hombre de este siglo se identifica con una "sombra de acero", una "máquinaria de cálculo", etc.: ". . hueca voz de tambor de pobre llanto,/ yo, sin brisa, sin astro, con un ojo de buey redondo y ancho,/yo, digno soy de muerte organizada" (pp. 27-28). Uno de los más logra. dos poemas, de alta y eterna poesía, a la vez sencilla y honda, cargada de emoción humana, de esencia de las cosas, de sorpresivas imágenes y de comunicación plena y transparente, es el titulado "Muerte de Gabriela Mistral":

Yo te canté con labios de pureza, con una voz salida de mi entraña, con la humildad nacida de la caña en un éxtasis niño de belleza.

Mientras soplaba el silencio, mientras el misterio se envolvía en su piel de venado y unas negras violetas caían en el mar;

.......................

y corrían caballos rojos en el viento

tratamos de vivir debajo de los párpados, soplar la lluvia y el viento hacia arriba, hacer de la nieve llamas y tender las manos hacia los cabellos de los muertos. Todo fue inútil porque el momento es como roca muerta junto al mar...

(p. 36)

Muestras de esta calidad hay muchas en Madurez de la muerte y se repiten en su Autobiografia (1962), poema de más de mil versos libres o romanceados, de diverso metro, rico en imágenes creacionistas, "posesiones" clásicas y sentidos simbólicos, donde no falta la deliberada técnica del anti-poema, tan en boga hoy, la "enumeración caótica" de ayer y siempre, el lugar común y la "metáfora de 
lo disimil", todo dentro de un itinerario de confesión exaltada que a veces linda con lo onírico y lo sobrerrealista:

La hermana está clavada contra el muro,

el rostro del hermano está en el polvo,

el cerebro del padre es un candado,

el corazón del hijo es un pescado.

El mundo suena cual campana rota,

la palabra del hombre es un lamido

de vaca de metal, y los abrazos

serpientes de algodones.

(p. 75$)$

Estos y otros ejemplos son suficientes, creo, para mostrar que Torres-Rioseco, como poeta, no está a la zaga del crítico e historiador de la literatura hispanoamericana, que tiene razón al situarse en las "nuevas tendencias" de nuestra poesía (en su Breve bistoria de la literatura chilena. México, 1956, p. 145, donde proclama que no pertenece a ninguna escuela, que detesta los "ismos" y que sólo confía en un crítico imparcial y eterno: el Tiempo), y que será preciso estudiarlo, entenderlo, sentirlo y otorgarle el lugar que le corresponde en el Parnaso de América.

State University of Iowa

Alfredo A. Roggiano

Homero Castillo, El criollismo en la novelistica cbilena. México: Ediciones de Andrea, 1962.

La doctrina de la escuela criollista de la literatura chilena remonta, según parece, al discurso con que José Victorino Lastarria inauguró, el 13 de Mayo de 1842, la Sociedad Literaria constituida por algunos de sus alumnos del Instituto Nacional, y fue revivida, mucho tiempo más tarde, cuando un crítico francés avecindado en Chile, Emilio Vaisse, examinó la obra de Mariano Latorre y sus tendencias, al través de Cuna de cóndores (1918). En el camino, claró está, fue más de una vez reforzada con nuevos ápices, como en 1860, por ejemplo, cuando Alberto Blest Gana se incorporó a la Facultad de Filosofía y Humanidades de la Universidad de Chile, que también tocó ese tema en su discurso de orden.

En nuestro entender, se trata de una inclinación psicológica permanente e inexcusable, que forma parte del instinto de conservación. Por preferir el menor esfuerzo, el escritor tocará lo que tiene más próximo, sus experiencias personales, sus recuerdos, y de consiguiente, el panorama que literariamente abarquen sus ojos ha de ser, en la mayotía de los casos, el que dominaron los ojos del niño, el que le ha seguido acompañando la vida entera, el de la tierra nativa. No se necesita postular una doctrina del ejercicio literario para llegar a este resultado, y en consecuencia, la literatura nativista, o vernácula, o criollista - como se prefiere decir 
en Chile-, es obvia. Dicho de otro modo: todos los escritores son criollistas de su suelo natal, con las pocas excepciones que la propia historia literaria se encarga de señalar.

Estas reflexiones no pretenden en grado alguno restar mérito al estudio de Homero Castillo, profesor de Northwestern University, Evanston, Illinois, titulado El criollismo en la novelistica chilena, que hemos leído con interés y no poco fruto. Habríamos preferido, acaso, que se dijese novela en lugar de novelística, puesto que esta voz parece adjetivo antes que sustantivo y es, en fin, algo rebuscada. Pero por palabras de más o de menos no vamos a disputar en presencia de un libro que contiene no pocas útiles nociones: dedicarse a las voces sería, esta vez, tomar el rábano por las hojas, feo delito que no querríamos de ninguna manera cometer.

El libro del señor Castillo contiene un capítulo (p. 8-18) sobre Lastarria, de quien se estudia $E l$ mendigo, cuento publicado en 1843 que, de una parte, lleva a la práctica la lección de criollismo que se daba en el ya mencionado discurso, y de otra abre la serie de relatos novelescos a que el autor dedicó una apreciable porción de su laboriosa existencia. En capítulo separado se estudia a Federico Gana (p. 19-29), al través de uno de sus relatos más reptesentativos, La señora. Este cuento de Gana, el más recordado de los suyos, formó en una colección titulada Días de campo (1916), con la cual Gana confirmó, en la edad madura, los muchos títulos que había conquistado hasta entonces a la admiración de sus lectores. Debe añadirse, al paso, que el análisis intentado por el señor Castillo de esta producción de Gana, no es sólo exhaustivo sino que contiene innumerables reflexiones dignas de la consulta porque revelan ahincado estudio.

En capítulos sucesivos se estudia también la producción de Rafael Maluenda (p. 69-72), de González Vera (p. 73-83), de Oscar Castro (p. 84-95) y de Francisco A. Coloane (p. 96-107). Pero el mayor peso de estas páginas gravita hacia la obra de Mariano Latorre, a quien se dedican cuatro de los diez capítulos del libro. Veamos, pues, cuáles son los temas que ocupan especialmente la pluma del crítico.

Le juzga en el intento de hacer literatura nativista o vernácula (p. 30-40), al través de documentos del propio Latorre en que éste explicó, a modo de resumen de toda su obra, la intención que le había animado al escribir. Le juzga, en seguida, a propósito de La isla de los pájaros, como descripción del ambiente isleño (p. 41-54), no sin advertir, de paso, que este libro es el último que Latorre publicó y uno de los suyos en que más a fondo queda aplicada su peculiar manera de componer. Le trata, además, como autor de relatos de ambiente urbano, que en su obra son los menos en número (p. 55-61), si bien hay algunos entre ellos extremadamente representativos de la fisonomía del autor, como La paquera (1958), novela póstuma. Y, finalmente, le juzga en globo, en sus rasgos más generales, haciendo otra vez uso de las propias palabras de Latorre (p. 62-68):

Al destacar los rasgos sobresalientes de la obra de Mariano Latorre -escribe su crítico, p. 62-, hemos procurado establecer, a base de las propias declaraciones del autor; que la afición por él demostrada hacia el criollismo se gestó fundamentalmente en el amor que sentía por su 
tierra y por sus paisanos. Vale la pena recalcar, al respecto, que era hijo de españoles y franceses, y que fue criado en un medio saturado de gustos y costumbres extranjeras.

Esta observación debe ser hermanada con otra. Latorre, como se ve en notorios sitios de sus obras, era muy consciente de la existencia de las razas humanas, hasta el punto de ser abiertamente racista, si por tal se entiende aquel individuo que se cree perteneciente a una raza superior a otras, sea por el color de la piel, sea por el nivel medio de talento, destreza, inteligencia, etc., de sus hijos. A él, pues, como vástago de españoles y de franceses, cual anota su crítico, se le representaba como inferior, hablando en términos racistas, el medio ambiente humano dentro del cual debía vivir, especialmente en el campo, pues allí distinguía, sin mucho esfuerzo, las huellas físicas de las sangres de las razas aborígenes, mantenidas indelebles a pesar del largo mestizaje que en ellas se ha practicado. El amor mentado por el señor Castillo existe, sin duda, pero algunas veces podría ser considerado piedad (del ser superior cuando trata con un inferior), lástima (del ser superior que consuela al inferior), extrañeza (del ser superior que confiesa no entender lo que quiere el inferior), etc. Estos sentimientos quedan subrayados por el propio autor de estas páginas de comentario a la obra de Latorre, donde aparecen algunos fragmentos de La isla de los pájaros (p. 43-46). Debe notarse, para que entiendan el asunto los no iniciados, que Latorre fue, generalmente, personaje de sus cuentos, que se mezclaba en ellos con su identidad personal o con poco disfraz, para ir comentando los sucesos a medida que éstos ocurrían, de modo que aquellos sentimientos de piedad, lástima, extrañeza, etc., que hemos señalado, es en él muy fácil percibirlos. Enemigo, en general, de simbolizar, Latorre decía las cosas claramente, pan pan, vino vino, de manera que los valores de su literatura son de percepción inmediata y no admiten interpretaciones equívocas.

En resumen, el libro del señor Castillo, integrado por una copiosa bibliografía (p. 108-10), encierra multitud de informaciones para aquilatar la evolución del criollismo, desde su aparición en las letras chilenas en 1843, con la publibación de $E l$ mendigo de Lastarria, hasta escritores de promociones recientes como Castro y Coloane (ambos nacidos en 1910), y pasando por los principales criollistas de las generaciones intermedias, Gana (1868), Maluenda (1885) y Latorre (1886). Si a estos nombres se añadieran ottos del período inmediatamente siguiente al de Lastarria, como Blest Gana (1830), Zorobabel Rodríguez (1839), y algunos en épocas más recientes, como Senén Palacios (1855), Manuel J. Ortiz (1870), Díaz Garcés (1878), tendríamos una conclusión a la vista.

La conclusión es que la presencia activa de una escuela de literatura nativista (en Chile se la prefiere llamar criollista) se nota en los géneros narrativos (novela y cuento) a lo largo de la evolución histórica de estos géneros, desde que se comenzaron a cultivar en el país (1843) hasta el día de hoy; que esta escuela coexis. te con otras en que predominan la simbolización, la alegoría, etc.; que no es obligatorio en ella considera sólo seres de extracción campesina, ya que otros grupos sociales también pueden ser estudiados con fruto, y que lo previsible es que dicha escuela siga manifestándose en años sucesivos.

Entre los criollistas significativos que echamos de menos en este libro, se 
nos ofrecen, al pronto, los nombres de Luis Durand, entre los desaparecidos, y de Lautaro Yańkas, entre los contemporáneos, ambos con obra de gran volumen y de notable mérito. Es de esperar que el crítico les dedique sendos capítulos en futuras ediciones de este libro o en otros de sus estudios. La extrema pericia que revela en el análisis de la obra literaria, la prudencia con que emplea los testimonios, inclusive cuando se hacen fuego, dejan ver que nos encontramos ante un crítico literario de ágil intelecto y de privilegiadas condiciones en la exposición, facultades que deben aprovecharse al máximum para la debida ilustración de las letras chilenas.

Tulane University

Raúl Silva Castro

María Urzúa, Altovalsol. Santiago de Chile: Ediciones del Grupo Fuego, 1961.

En medio de la poesía chilena contemporánea, tan fértil en todo, descuella el nombre de María Urzúa, cuyo libro Altovalsol es el último en fecha, pero seguramente no será el último que la autora publique. Confiesa ella que anda en busca de la "perfecta palabra", viejo, tenaz empeño de todos los escritores de todas las lenguas y razas. En la "perfecta palabra" encontratemos tal vez el ritmo musical de la prosodia, el aliento de antiguas generaciones, nuestro propio aliento, y al hallarla trataremos de fijarla en el papel para que con nosotros, sus halladores, la reverencien todos los humanos. Ahora bien, ¿dónde está la "perfecta palabra" tras la cual anda María Urzúa? Debe señalarse, al paso, que el nombre Altovalsol corresponde a un sitio geográfico del Norte Chico; pero el libro de María Urzúa no está dedicado ni a Altovalsol ni a región alguna de Chile: es más bien abstracto. Hay eso si, un poema titulado Altovalsol donde se define el sitio:

Un fervor majestuoso se tiende en la pradera y prolonga confusos perfiles de tinieblas.

Ya comienza el desamparo de la tierra, embellecida en la hora de la siesta, bajo la mirada integral del firmamento.

El viento la dejó desvalida y a ciegas, en secretas ensenadas de sombra.

Alto, más alto que estos montes y estos cielos va el sol.

En esta última frase está contenido, como se ve, el nombre regional, y por la autoridad de María Utzúa podemos ya asegurar que Altovalsol se llama así con referencia a la imagen que sus habitantes se hicieron del sol sobre las cumbres.

¿Está alli la "perfecta palabra"? Parece que no; sigamos buscando. En "Hoy" la poetisa canta la gloria de la luz, y en otros fragmentos insinúa delicadas sugerencias de su propio tránsito por el mundo, en menudas confesiones. Hay una excepción, y vale la pena detenerse en ella. En "Una ventana" ensaya la autora salirse de su ámbito personal, y éste es el resultado: 
Una simple ventana, hacia un mundo tan ancho, cruzado por los cielos en cendales de alba.

Respiran los cristales blanca fiesta de almendros ceñidos de luciérnagas. Y la danza del ceibo enardece la llama que incendia la montaña

a la orilla del sueño.

Y mis lunas destellan en ascenso de alas sobre espacios tosados. No importa si mañana, a la hora del descenso, se rezagan en niebla.

Una simple ventana.

Si se nos permite imaginar que hay aquí un paisaje visto desde el interior del cuarto, y que en ese paisaje luna, niebla, almendros, ceibo, ocupan el reducido espacio que cada uno pudiera reivindicar, también se nos estaría permitido aplaudir el intento de la autora y declararlo cumplido. $Y$ a propósito, ¿se encuentra aquí la "perfecta palabra"? Bueno, tanto no; no seamos tan exigentes. Si miles de poetas han venido procurando hacerla suya, a lo largo de tantos siglos, ¿qué mucho será que María Urzúa tampoco la logre del todo, si bien ande en sus ve. cindades, casi rozándola?

En el fragmento que hemos transcrito..., y no nos atrevemos a llamarlo poema, nombre que acaso le viniera demasiado grande; en el fragmento copiado hay una idea poética, la de la ventana al través de cuyos cristales se contemplan determinadas cosas; pero fuera de aquella idea hay bien poco más. La autora odia, al parecer, la labor sostenida, y antes que dedicarse a tallar en su gema para hacerla rendir todas las luces que dentro de sus entrañas yacen, y sin pulirla ni desbaratarla, sin preguntarse siquiera si ésta es la gema en cuya busca andaba, la lanza al libro. Exceso de prisa. Lo mismo cabe decir a propósito de "Ofrenda inútil", donde también divisamos la idea poética feliz, el meollo que pudiera servir de centro a una bella creación. Y aquí, nuevamente, se nos deja con el gusto en los labios, sin permitirle entrar hasta el corazón, porque María Urzúa, inquieta, acaso inconstante en su amor artístico, se aleja pronto y se va a otra cosa. ¿A dónde? Pues, nada menos que a "La perfecta palabra", pequeño, sutil poema que debemos conocer:

$Y$ si fuera verdad lo que dice el silencio, lo que oscila en la llama que vislumbra el arco vivo de mi pensamiento.

Si por sobre los bronces de la lluvia me viniera tu voz, ausente de sonidos, cayendo en gotas densas hacia adentro, en un grito salido de la entraña.

$Y$ yo reconociera la palabra perfecta, cuajada en sangre y fuego, en seda y en aromas. $Y$ si fuera verdad, me volcara en el viento $y$ en las lenguas del agua. 
$Y$ estampara en el aire para siempre, única, pura, nítida, la perfecta palabra.

De estos versos desprendemos, primero, que la palabra a la cual la autora llama perfecta es la que haya de proferir una determinada persona, un hombre desde luego, en determinado trance; y, segundo, que esta palabra habrá de parecerle perfecta a quien la reciba como complemento de la caricia, porque la está aguardando y porque encierra, para ella, la solución de un entrañable problema sentimental. La perfecta palabra es, pues, en lenguaje cotidiano, la que lleva un mensaje de amor. $Y$ en el lenguaje de la poesía, ¿qué será? Lo mismo, sin duda, ya que un buen porcentaje de todos los poemas escritos en el mundo fueron motivados por el amor; y todo hace presumir que así seguirá siendo hasta el futuro más remoto.

Podemos ahora, acaso, recapitular e intentar un diagnóstico.

María Urzúa se nos muestra en Altovalsol como una poetisa en potencia, capaz de alumbrar ideas poéticas apropiadas para armar el poema, si a ellas se agregan imágenes, estilo y gracia, es decir, todo lo que se presume que el poeta domina en su ejercicio y que perfecciona y sublima con la práctica. Por eso mismo, lamentamos que una indiscreta prisa deje, a nuestros propios ojos, la faena a medio hacer, esto es, el poema en esbozo, la idea poética central sin los añadidos que habrán de brindarle relieve. Y lamentamos sobre todo la falta de oído, es decir, la ineptitud que tan reiteradamente exhibe la autora para ponderar la cláusula de modo que las sílabas no sobren con escándalo, los acentos caigan donde deben caer y no en cualquier parte, y el ritmo se logte.

María Urzúa comenzó su comercio lírico en Río amargo, libro que fue publicado en 1957. Son, pues, pocos los años que la separan de sus primeros ensayos, y mucho le queda por andar si quiere, como es probable, alcanzar la maestría con esfuerzo. Con Altovalsol se acerca a la meta, y sin exagerar podría decirse que a la vuelta de la esquina la espera ya, única, nítida, la perfecta palabra...

Tulane University

Raúl Silva Castro

María Angélica Alfonso, Mundo compartido. Santiago de Chile: Editorial Universitaria, 1961.

Tres años ha, cuando irrumpió en las letras María Angélica Alfonso con su libro Tiempo limitado (1958), una feliz sorpresa dejó en suspenso a sus comentaristas. ¿Qué bien cantaba los tormentos propios del amor; inclusive cuando se le divisa a la distancia y cubierto de crespones de luto! La alegría de ayer, ligeramente deformada ya por la melancolía de lo irremediable, la había inspirado hasta el extremo de llevarla a dar forma de imágenes literarias a recuerdos sutiles y peregrinos, de los que habitualmente el ser amante no quiere compartir con nadie que no sea su alter ego. Las cosas han cambiado desde entonces, y en su 
obra de hoy, Mundo compartido (Editorial Universitaria), se lee una especie de nanifiesto donde entre otras cosas se dice: "No perpetúo la propensión ornamental y esotérica que arranca tonos admirativos al snob y a aquellos sujetos dramáticamente superficiales que han contribuido a averiar de manera irremediable la nueva poesía de mi patria. Los fabricantes de bordados, de púrpuras, de divagaciones, de papelismos y de cogotismos, han estado en vigencia un tiempo demasiado largo. Yo, como el negro de la fábula de Juan Manuel, nada tengo que perder si digo que el rey va desnudo. No aspiro a que mi poesía entre a los museos. Ni temo que por ella me levanten una estatua. Solamente en silencio, siempre escribo. Y en mi faena, cada día más sola" ( $p .7)$. Y en la dedicatoria se lee en seguida: "Dedico este libro a quienes hicieron posible su publicación: a mi gente, a mis jueces, a mis verdugos" (p. 9).

Es propio de la sensibilidad literatia, enardecida en la lucha por alcanzar la nombradía, el sentir delirio de persecución. Será clásico en las letras chilenas el recuerdo de cierta poetisa fallecida hace muy poco tiempo, a la cual, después que el gobierno de Chile la había colmado de favores, se la oyó decir que no podía volver a su patria porque aquí se la odiaba y escarnecía. Un crítico osó insinuar que no todo en la obra de la poetisa era perfecto, y entonces ella, ganada ya en pleno por el delirio de persecución, declaró que ese hombre era un infame. $Y$ así, por donde se escarbe en las declaraciones de Gabriela Mistral, siempre aflorará la queja en que se materializaba su delirio.

Tememos que algo parecido esté ocurriendo con María Angélica Alfonso, y a tiempo y con respeto se lo decimos. ¡Cuidado con el delirio de persecución! Es compatible con el máximo talento literario, pero el poseerlo no implica ciertamente que se posee aquel talento. Lo que sí implica es una especie de rebajamiento del alma, compatible también con el talento, pero que siempre ganaremos si lo dejamos sumergido en la sombra, como una de tantas renuncias de la espontaneidad a que nos obligan el convivir pacífico con los demás hombres y las buenas maneras. ¿A qué viene, por ejemplo, en aquella dedicatoria, eso de hablar de jueces y de verdugos? Los jueces propios de la escritora son los críticos literarios, y éstos han sido con ella no generosos sino justos. Habrian sido generosos si hubieran disimulado sus errores y tendido un velo de complicidad sobre los deslices y las fallas artísticas; pero como tales fallas no existen, han sido justos solamente, al aplaudirla y alentarla. Esto con los jueces; ¿qué decir de los verdugos? Es verdugo el hombre a quien compete ejecutar la sentencia de la justicia, esto es, de los jueces, que como letrados no tienen por qué ser al mismo tiempo buenos matanceros. ¿Ha tenido verdugos la autora? Meditemos un poco, pensemos las cosas en su prístina desnudez, y hasta, si se quiere interpretemos con latitud. Es verdad que ciertas personas (no los críticos literarios, desde luego) la zahirieron por haber hallado en sus versos de Tiempo limitado algunas exhibiciones candorosas de erótica complacencia, a las cuales, por gazmoñería, creyeron falaces y de mal gusto. Pero no parece que esos tales hayan llegado hasta el punto de que sea cuerdo llamarles verdugos. Majaderos sí, sin duda; pero... verdugos. ¡Vamos, Maria, Angélica, repórtese, y sobre todo no se deje ganar por el delirio de persecución!

Siento que $\in 1$ preámbulo haya sido un tanto largo; pero el tema lo merecia. 
Convencer a esta escéptica de que posee talento poético y de que le conviene empleatlo bien (esto es, menos en manifiestos y en dedicatorias agresivas que en versos), es una tarea que me parece fácil. Para ello basta abrir su libro de hoy, Mundo compartido, leerlo, saborearlo, $y$, sobre todo, repasar aquellas composiciones que mejor nos quedaron sonando tras la primera lectura. En ese número cuento "Amar y morir" (p. 17), enérgica y a la vez dulce sintesis de lo que se siente cuando se ama. Y cuenta, asimismo, "Ruinas de Toltén" (p. 33). En estos pocos versos me parece que se explica el fenómeno de la permanente e implacable destrucción que se da en la poesía de Neruda y que llamó ya la atención de sus críticos, desde Amado Alonso. Es, al parecer, el sur mismo de Chile el que se resquebraja, de modo que no debe extrañarnos que algunos poetas de esa región -Neruda ayer, María Angélica hoy- lleven a sus versos el sentimiento de la disgregación incoercible. El poema dice así:

Escucho en las maderas gotear el tiempo, $y$ por los troncos carcomidos oigo deslizarse al insaciable enemigo.

Hay que estar en el Sur, pasar los años en sus pueblos abiertos, oír el silbido de los trenes en la sombra, sentir al mar en Nigüe, sentir al viento, para entender la caída de todos y llegar a la Historia y al Olvido.

Amanece un Invierno tembloroso, tapizado de estatuas y cemento, vestido de la propia confusión, como por manto siniestro.

Desde Cayulfe a Boldos hay un largo silencio, y entrando hacia Toltén el olor de los muertos.

De corte similar son otros poemas, entre los cuales debe, por motivos de justicia, citarse "Invierno en pueblo chico" (p. 37), que es una buena miniatura de la vida vulgar. Vamos, en cambio, hacia la protesta social en "Hambre" (p. 45), donde se pregona la vieja historia del niño hambriento que se exhibe "a su mendrugo asido" junto a lo más suntuoso y exclusivo que ofrece la ciudad, el centro deportivo de la alta burguesía. $Y$ nos quedamos en el cálido elogio de la Frontera con sus hielos, su cierzo, su fronda en "Paisaje de Cautín" (p. 50).

Ahora podemos asegurar que para María Angélica Alfonso el mundo está compartido entre ella y estos pequeños rasgos que ha ido atisbando a medida que vivía en su rincón sureño, y que en ellos debe ocupar también un sitio, y nada vergonzante por cierto, el espacio que llenan los araucanos con sus ceremonias, entre las cuales vemos supersticiones y conjuros pintorescos, con enumeración de voces toponímicas. La adhesión de la poetisa al ambiente en que vive, grande o pequeño, oscuro o luminoso, nos parece perfecta y cabal, y cuando llega el 
momento de manifestarla, nada le escatima en la oblación de su arte. Porque hay arte, sin duda, en estos versos, aun cuando a veces desgarbados. La moda del día exige al escritor cierta continencia verbal, porque se teme hacer el ridículo si se esfuerza la voz y si en lugar de gemir apenas, se procura dar ritmo métrico al gemido. María Angélica no es una excepción, acaso porque no desea llamar demasiado la atención hacia su obra, y se ciñe a la moda de su tiempo con cierta docilidad que bien podríamos reprocharle si no temiéramos haber aglomerado ya en esta nota excesivas reservas.

De todos modos, y volviendo al comienzo, vale la pena advertirle que no está bien sentirse perseguida y hostigada por el mundo, pues en suma no podría decirse que es "el mundo" aquel pequeño grupo de seres incomprensivos y añejos que un día pretendieron estorbar el paso de la poetisa. Yérgase ella sobre sus coturnos, acorácese en la posesión de su propio yo, recuérdese madre como la santa mujer cuyo nombre lleva, y podrá sonreír caritativamente sobre las miserias que alguna vez le salieron al camino y pretendieron echarla por tierra. Sin despreciar a nadie y sin odiar a nadie, siga adelante, aunque se sienta "cada día más sola...". 
